\title{
The early Toarcian (early Jurassic) ostracod extinction events in the Iberian Range: The effect of temperature changes and prolonged exposure to low dissolved oxygen concentrations
}

\author{
Carmen Arias* \\ Departamento de Paleontología e Instituto de Geociencias (IGEO), Facultad de Ciencias Geológicas, Universidad Complutense de Madrid, 28040 Madrid, Spain
}

Keywords:

Early Jurassic

Metacopine

Mass extinctions

Ostracoda

Low oxygen episodes

Water temperature

\begin{abstract}
A B S T R A C T
The early Toarcian extinction event, once regarded as spanning in the late Pliensbachian-early Toarcian boundary period, actually occurred in two distinct phases in the early Toarcian of the Iberian Range. The first episode occurred in the Mirabile Subzone, Tenuicostatum Zone and is characterised by the disappearance of about $12 \%$ of ostracod species and one suborder, the Metacopina (Superfamily Healdioidea). This study shows that this suborder disappears during stratigraphical intervals that are considered to be representative of low oxygen conditions in the Iberian Range. The collapse of marine ecosystems (affecting up to $40 \%$ of ostracod species) in the Elegantulum Subzone, Serpentinum Zone was most likely triggered by a sudden and widespread lethal increase in seawater temperature. These combined processes of oxygenation and temperature change are considered to be responsible for the profound changes in marine environments that resulted in the early Toarcian ostracod extinction in the Iberian Range.
\end{abstract}

\section{Introduction}

Out of the proposed five major Phanerozoic extinction peaks, the Pliensbachian-Toarcian boundary extinction episode has prompted many questions about its magnitude and speed, and selectivity of the extinction triggering mechanisms (Little, 1996; Hallam and Wignall, 1997). Ostracods dwell in every aquatic environment and, in spite of their notable adaptive capability, many marine species were affected by the early Toarcian (early Jurassic) biological crisis in the Iberian Range (Arias, 2008a). Arias and Whatley (2009) recognised an important increase in the ostracod species diversity from the Hettangian to the Pliensbachian, reaching maximum diversity values in the Spinatum Zone (around $60 \%$ ). This peak was followed by a sharp diversity decrease through the Tenuicostatum and Serpentinum zones, and then a gradual increase through the remainder of the Toarcian (Arias and Whatley, 2004; Arias, 2008a).

Thus, an important ostracod crisis seems to have occurred at the close of the beginning of the Toarcian. Trying to understand all these changes, this paper analyses the ostracod extinction pattern in three sections in the Iberian Range (Spain), where it is possible to

\footnotetext{
* Departamento de Paleontología e Instituto de Geociencias (IGEO) Consejo Superior de Investigaciones Científicas and Universidad Complutense de Madrid (CSIC/UCM), Facultad de Ciencias Geológicas, UCM, Juan Antonio Novais, 2, 28040 Madrid, Spain. Tel.: + 349139434 48; fax: + 343944849 .

E-mail addresses: cariasf@geo.ucm.es, cariasf@ucm.es.
}

analyse multiple replacements, disappearances and appearances in the continuous ostracod record across the Pliensbachian-Toarcian boundary. The three sections provide one of the most complete ostracod record not only in the Iberian Range, but also in western Europe and can be helpful for understanding ostracod faunal change at the beginning of the Toarcian.

With a relatively low extinction rate, Ostracoda is one of the best fossil groups for studying those factors influencing this kind of important biological crisis. With many potential causes, the early Toarcian ostracod extinction has caused much debate in the scientific community for over twenty years (Lord, 1982; Arias, 2000; Boomer et al., 2008). Extrinsic causes have long been favoured (e.g. sea-level changes, warming episodes, fluctuating low oxygen levels and/or nutrient dynamics) which led to decimation of marine ostracods (Arias, 2000; Arias and Whatley, 2004, 2005). However, none of these hypotheses have been totally convincing, in part because they could not account for some critical aspects of the ostracod record, such as the selective nature and variable rates of extinctions, the stepwise extinctions, and the timing between a specific environmental condition and the early Toarcian extinction episode. This problem is particularly relevant in the case of extinction processes affecting the ostracods of the Iberian Range. A comprehensive review of the voluminous literature on early Toarcian mass extinctions is beyond the scope of this study (Lord, 1982; Arias, 2007, 2008a; Boomer et al., 2008; Arias, 2009). This research focuses on some of the most potential critical mechanisms of extinction: low oxygen levels in the water and changes in water temperature. 


\section{Material and methods}

The ostracods described in this study were recovered from three sections located in the Iberian Range, north-eastern Spain (Fig. 1A, B). These areas were previously studied by Arias (1997) and a new sample collection work has been made in the same sections as part of a new high resolution stratigraphic study carried out by the Jurassic Research Group (UCM Universidad Complutense de Madrid). The Upper Pliensbachian-Lower Toarcian sediments studied (Fig. 2) belong to the Ablanquejo Group, which comprises three formations: the Margas grises del Cerro del Pez Formation, the Calizas Bioclasticas de Barahona Formation and the Alternancia de Margas y Calizas de Turmiel Formation (Gómez and Goy, 2000). The Pliensbachian-Toarcian boundary has been recorded across the last two formations. The Calizas Bioclásticas de Barahona Formation consists of richly fossiliferous and bioturbated brown to yellowish bioclastic limestone, with ferruginous deposits in the upper part. The Alternancia de Margas y Calizas de Turmiel Formation is a sequence of limestone alternating with marl, containing a very rich and diverse fossil fauna of ammonites, brachiopods and bivalves (Fig. 2) (Gómez and Goy, 2005). Three sections have been sampled in detail: two located in the Aragonese Branch (Ariño and Moneva sections) and one section in the Castilian Branch (Perales de Alfambra section) (Fig. 1A). The Ariño section (AR, Fig. 1B) is exposed along two ravines near the village of Ariño, Teruel (Mapa Geológico de España, no. 467 “Muniesa", scale 1:50.000; Lat: $4^{\circ} 2^{\prime} 52^{\prime \prime} \mathrm{N}$; Long: $0^{\circ} 37^{\prime} 36^{\prime \prime} \mathrm{W}$ ). The Moneva section (MO, Fig. 1B) is located at the Barranco de la Vega, $6 \mathrm{~km}$ south of the town of Moneva, Zaragoza (Mapa Geológico de España, no. 467 “Muniesa”; Lat: $41^{\circ} 5^{\prime} 50^{\prime \prime} \mathrm{N}$; Long: $0^{\circ} 48^{\prime} 15^{\prime \prime} \mathrm{W}$ ). The Perales de Alfambra section (PA, Fig. 1B) is situated close to the village of Perales de Alfambra at the Sierra Palomera Mountain, Teruel (Mapa Geológico de España, no. 542 “Alfambra”; Long: $40^{\circ} 38^{\prime} 25^{\prime \prime} \mathrm{N}$; Lat: $0^{\circ}$ $\left.55^{\prime} 45^{\prime \prime} \mathrm{W}\right)$.

Forty one samples were collected from the mudstone and marl of the Calizas Bioclasticas de Barahona Formation (Upper PliensbachianLower Toarcian) and from the marl of the Alternancia de Margas $y$
Calizas de Turmiel Formation (Lower Toarcian). The sample processing consists of drying, weighting out $100 \mathrm{~g}$ samples and dispersing them in a solution of hydrogen peroxide, sodium hydroxide and water. The disaggregated samples are washed through sieves with five meshes of the following diameters $>60,125,250,500$ and $1000 \mu \mathrm{m}$. All ostracods from $>125 \mu \mathrm{m}$ fractions are picked and mounted onto cardboard microscope slides. The fraction $>60 \mu \mathrm{m}$ is always inspected, revealing little influence on diversity and composition. A total of 8510 specimens have been described and assigned to a total of 46 species in the three studied sections (Table 1).

\section{Results}

The Pliensbachian-Toarcian ostracod record in many European areas is rather poorly represented (Arias, 1997, 2000). The Iberian Peninsula probably displays one of the most comprehensible records of this fossil group through this interval. In the Iberian Range sections, the first pronounced ostracod faunal turnover is recorded in the Mirabile Subzone, Tenuicostatum Zone, when metacopines became extinct (Figs. 3-6). This first crisis is manifested by the replacement of the distinctive late Pliensbachian ostracod assemblages dominated by three species of healdioids (metacopines): Ogmoconchella adenticulata (Pietrzenuk, 1961) (Fig. 7.3), Ogmoconchella aequalis (Herrig, 1969) (Fig. 7.5) and Ogmoconchella aff. Ogmoconchella aspinata (Drexler, 1958) (Fig. 7.4) and several large cytheroids, such as Gramamella apostolescui (Gramann, 1962) (Fig. 8.2), Ektyphocythere aff. Ektyphocythere vitiosa (Apostolescu, 1959) (Fig. 8.6) and Kinkelinella tenuicostata Martin (1960) (Fig. 8.7); one dominated only by cytheroids, such as Ektyphocythere dharennsourensis Boutakiout et al. (1982) (Fig. 8.5), Kinkelinella sermoisensis (Apostolescu, 1959) (Fig. 8.8-9), and Kinkelinella sp. B (Fig. 8.10); and two late Pliensbachian species, Liasina lanceolata (Apostolescu, 1959) and Cytherella toarcensis Bizon (1960) range through (Fig. 7.6). In the three sections, the lower part of the Barahona Formation is dominated (Figs. 3-5) by two healdioid species O. adenticulata (Pietrzenuk, 1961) and Ogmoconchella

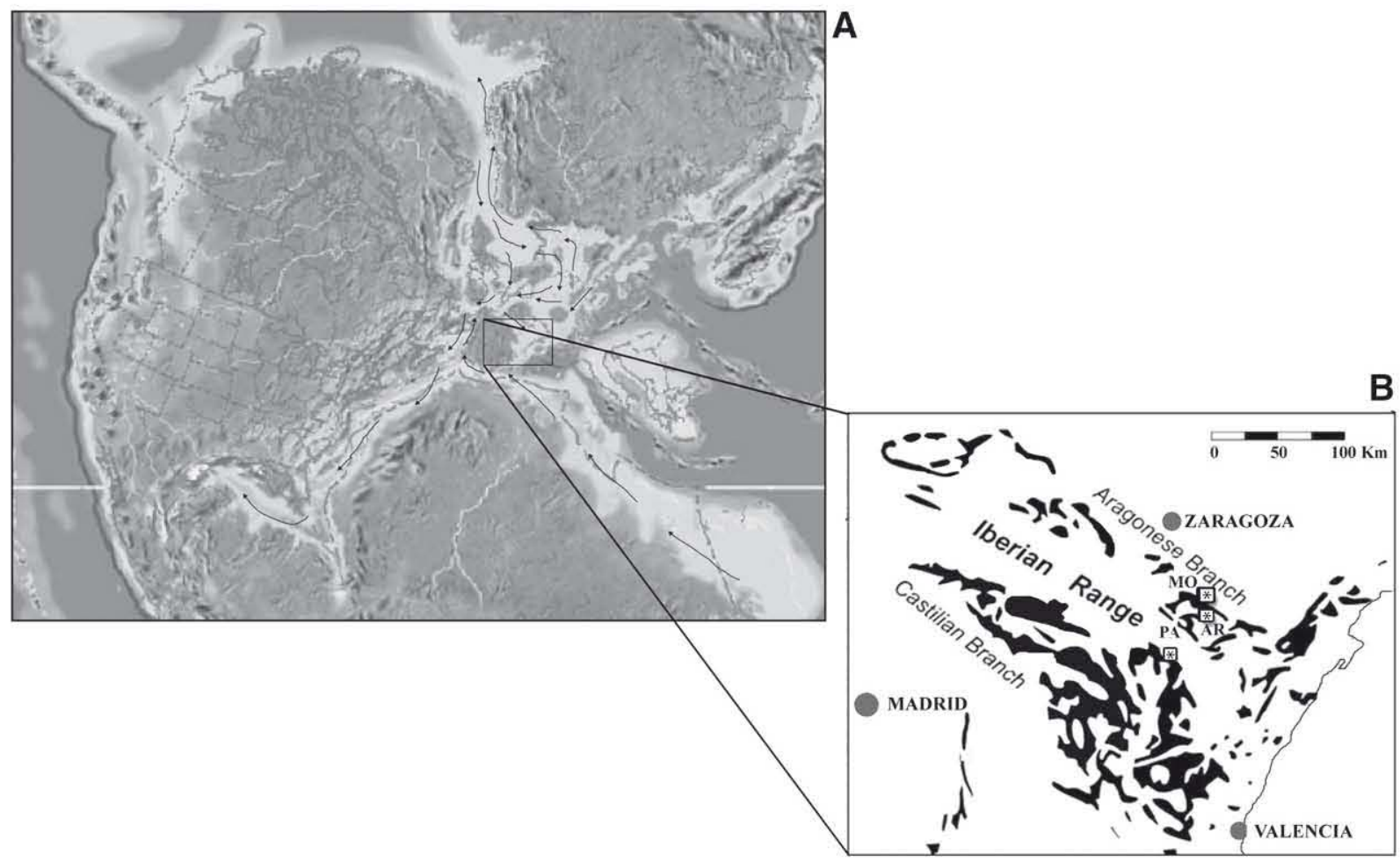

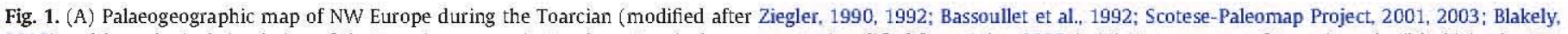

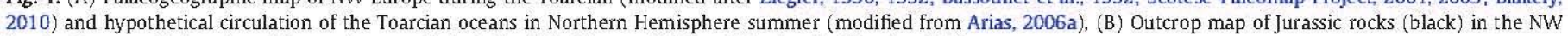
Iberian Range, with location of the sections studied: Ariño (AR), Moneva (MO) and Perales de Alfambra (PA). 


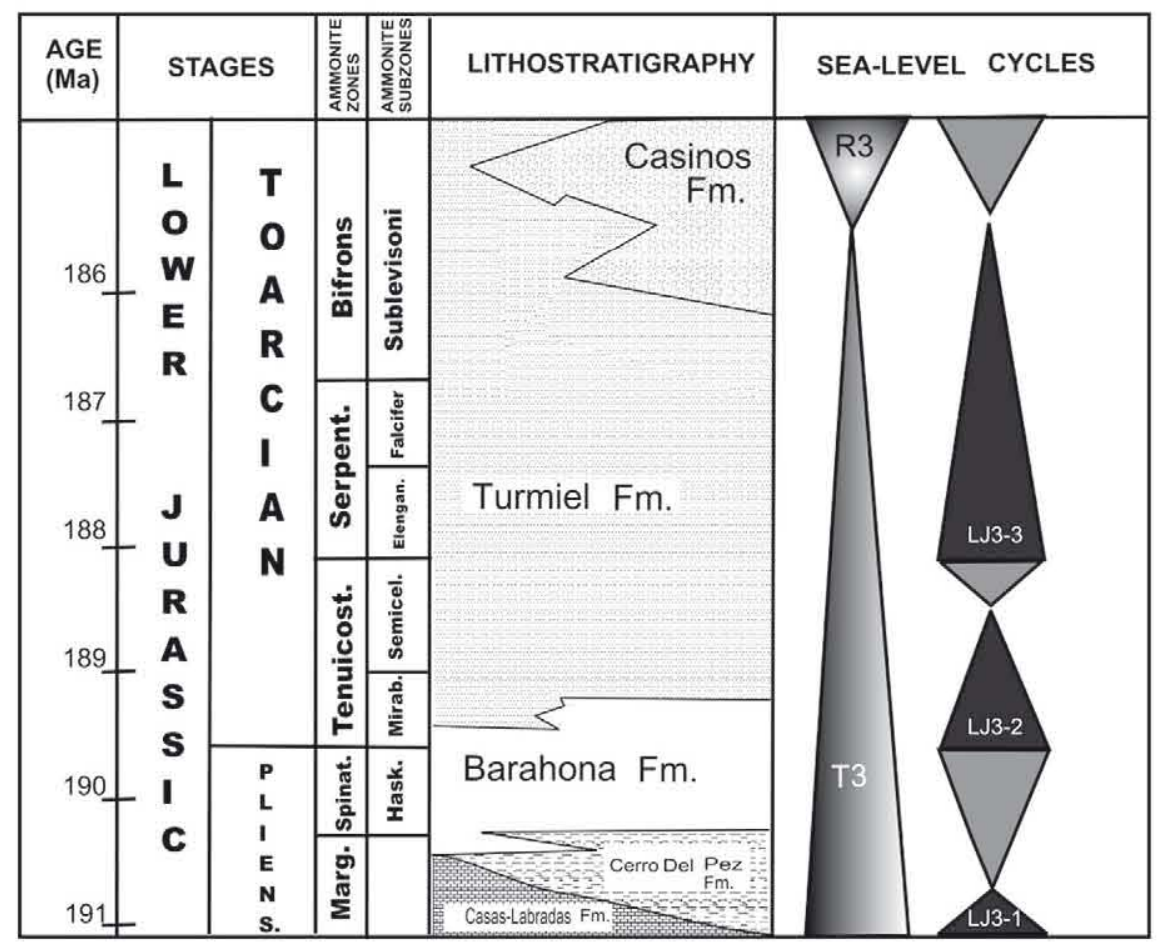

Fig. 2. Correlation chart of the Pliensbachian-Toarcian facies cycles recognised in the Iberian Range (Gómez and Goy, 2005; Arias, 2007).

aff. O. aspinata (Drexler, 1958). In the upper levels of the Upper Pliensbachian Turmiel Formation exhibits the first evidence of a biotic change, marked by a sharp decline in smooth healdioids (O. adenticulata (Pietrzenuk, 1961), Ogmoconchella aff. O. aspinata (Drexler, 1958)) and their replacement by large cytheroids (Ektyphocythere aff. E. vitiosa (Apostolescu, 1959) and G. apostolescui (Gramann, 1962)) accompanied by one cypridoid, L. lanceolata (Apostolescu, 1959) (Figs. 3-5). At the Pliensbachian-Toarcian boundary, within the Turmiel Formation, ostracod assemblages are initially dominated by Ektyphocythere aff. E. vitiosa (Apostolescu, 1959) associated with L lanceolata (Apostolescu, 1959) and Ogmoconchella aff. O. aspinata (Drexler, 1958). Metacopines dominate the Upper Pliensbachian Barahona Formation (basal part of the Spinatum Zone) in the three sections and cytheroids together with healdioids are the leading components of the Upper Pliensbachian Turmiel Formation ostracod assemblages (Figs. 3-5; Fig. 9A, B). Above the Pliensbachian-Toarcian boundary, Ektyphocythere aff. E. vitiosa (Apostolescu, 1959) associated with L lanceolata (Apostolescu, 1959) and the healdioid O. adenticulata (Pietrzenuk, 1961) continue to dominate the associations, typifying Mirabile Subzone ostracod assemblages (Figs. 3-5). The most abrupt and dramatic turnover in the ostracod assemblage occurs through the Mirabile Subzone (Fig. 6) with the rapid disappearance of all healdioid species. This extinction pattern contrasts with the results from other sections studied in the Iberian Range, such as Ricla or La Almunia de Doña Godina section (Arias and Whatley, 2004) where the disappearance of the metacopines did not match either the loss of Ektyphocythere aff. E. vitiosa (Apostolescu, 1959) and G. apostolescui (Gramann, 1962) or the appreciable decrease in abundance of L lanceolata (Apostolescu, 1959). Above this first crisis, after the Semicelatum Zone, assemblages become dominated by three cytheroids: K sermoisensis Apostolescu (1959), K tenuicostata Martin (1960) and Kinkelinella sp. B and one cytherellid, C. toarcensis Bizon (1960); meanwhile L. lanceolata (Apostolescu, 1959) that had survived the Mirabile crisis became one of the dominant species in the Toarcian Semicelatum Subzone (Figs. 3-5). Two extinction episodes are described in the three sections (Figs. 3-5). The first biotic crisis is manifested by the gradual disappearance of metacopines in the Mirabile Subzone (this phase represents the loss of $69 \%$ of the late Pliensbachian ostracod species). The second crisis occurs in the Elegantulum Subzone of the Serpentinum Zone (Fig. 6), where the Tenuicostatum ostracod assemblages are replaced by a new association dominated by cytheroids (Ektyphocythere anterocosta (Boomer, 1988) (Fig. 8.4), Ektyphocythere bucki (Bizon, 1960) (Fig. 8.3), K sermoisensis (Apostolescu, 1959) (Fig. 8.8-9), Praeschuleridea pseudokinkelinella Bate and Coleman (1975) (Fig. 8.11) and Bairdiacypris dorisae Knitter (1983), a bairdioid which became dominant in the Iberian ostracod assemblages in the Falciferum Subzone, Serpentinum Zone). In the three sections, polycopids survived the Elegantulum crisis (Figs. 3-6).

The variety of apparent extinction and survival patterns suggests something of the complexity of the ostracod extinction event in the Iberian Range. The most representative members of cytheroids and polycopids survived both events without suffering many losses; meanwhile the largest extinction event affected the metacopines. Of the two crises, the second makes the real impact of this extinction episode. Twenty species and almost more than $80 \%$ of the specimens disappear in the Elegantulum Subzone, mainly affecting significant species of cytheroids, bairdioids, cypridoids and cytherellids (e.g. L. lanceolata (Apostolescu, 1959) (Fig. 7.8) and C. toarcensis Bizon (1960)). Meanwhile one large cytheroid, E. dharennsourensis Boutakiout et al. (1982), became prevailing in the entire Elegantulum Subzone until its disappearance at the beginning of the Falciferum Subzone, Serpentinum Zone. The most significant emergence in this crisis is the appearance of B. dorisae Knitter (1983). One well-known Toarcian species became dominant in the Falciferum Zone: $K$ sermoisensis (Apostolescu, 1959) (Figs. 3-5, 6. 8.8, 8.9). This species together with several species of the genus Ektyphocythere (E. bucki Bizon, 1960 and E. anterocosta Boomer, 1988) became prevalent in the Elegantulum Subzone and the following zone (Fig. 6).

Thus, the ostracod extinction pattern in the Iberian Range follows two phases (Figs. 3-6): a first phase characterised by the disappearance of the metacopines in the Mirabile Subzone, Tenuicostatum Zone and their replacement by large cytheroids, with the cytherellids, bairdioids and cypridoids suffering significant species losses (Fig. 9A-B); and a second phase affecting all ostracod groups, especially cytherellids, cypridoids and bairdioids (Figs. 3-6, 9A-B). 
Table 1

List of ostracod species described in the Iberian Range.

\section{List of Taxa}

1. Aphelocythere kuhni (Triebel and Klingler, 1959)

2. Bairdia molesta (Apostolescu, 1959)

3. Bairdiacypris dorisae (Knitter, 1983)

4. Bairdiacypris aff. Bairdiacypris tumida (Ainsworth, 1987)

5. Cytherella praecadomensis (Knitter and Riegraf, 1984)

6. Cytherella toarcensis (Bizon, 1960)

7. Cytherelloidea anningi (Lord, 1974)

8. Cytheropteron byfieldensis (Boomer and Bodergat, 1992)

9. Ektyphocythere anterocosta (Boomer, 1988)

10. Ektyphocythere bucki (Bizon, 1960)

11. Ektyphocythere dharennsourensis (Boutakiout et al., 1982)

12. Ektyphocy there neumannae (Maupin, 1977)

13. Ektyphocythere aff. Ektyphocythere vitiosa (Apostolescu, 1959)

14. Eucytherura liassica (Bate and Coleman, 1975)

15. Gramannelia apostolescui (Gramann, 1962)

16. Infracytheropteron gwashense (Bate and Coleman, 1975)

17. Isobythocypris aff. Isobythocypris elongata (Blake, 1876)

18. Isobythocypris ovalis (Bate and Coleman, 1975)

19. Kinkelinella persica (Bate and Coleman, 1975)

20. Kinkelinella sermoisensis (Apostolescu, 1959)

21. Kinkelinella tenuicostata (Martin, 1960)

22. Kinkelinella sp. B

23. Liasina lanceolata (Apostolescu, 1959)

24. Liasina aff. Liasina vestibulifera (Gramann, 1962)

25. Liasina vestibulifera (Gramann, 1962)

26. Monoceratina amiingstadtensis (Triebel and Bartenstein, 1938)

27. Monoceratina michelseni (Riegraf, 1984)

28. Monoceratina striata (Triebel and Bartenstein, 1938)

29. Monoceratina ungulina (Triebel and Bartenstein, 1938)

30. Monoceratina sp.

31. Ogmoconchella adenticulata (Pietrzenuk, 1961)

32. Ogmoconchella aequalis (Herrig, 1969)

33. Ogmoconchella aff. Ogmoconchella aspinata (Drexler, 1958)

34. Paracypris aff. Paracypris redcarensis (Blake, 1876)

35. Paracypris sp.

36. Paranotacythere terquemiana (Jones, 1872)

37. Polycope discus (Fischer, 1961)

38. Polycope pelta (Fischer, 1961)

39. Polycope piumhoffi (Bate and Coleman, 1975)

40. Polycope tenuireticulata (Herrig. 1981)

41. Pleurifera harpa harpa (Klingler and Neuweiler, 1959)

42. Praeschuleridea pseudokinkelinella (Bate and Coleman, 1975)

43. Pseudomacrocypris subaequalis (Michelsen, 1975)

44. Pseudomacrocypris subtriangularis (Michelsen, 1975)

45. Trachycythere tubulosa tubulosa (Triebel and Klingler, 1959)

46. Trachycythere verrucosa (Triebel and Klingler, 1959)

\section{Discussion}

Despite the years since the first studies on the early Toarcian ostracod extinction, no causal hypothesis has been widely accepted, although most authors consider some mechanisms more realistic than others (Arias, 1997, 2000; Arias and Whatley, 2004, 2005; Boomer et al., 2008; Arias and Whatley, 2009; Gómez and Arias, 2010). Since it is extremely unlikely that a single event caused the extinction, as was advocated in the past, several explanations are generally considered, e.g. sea level variations, climate change, low oxygen levels, and competition. The two biotic crises are recorded in the Turmiel Formation (Figs. 3-5) which represent sedimentation in a low-energy open external platform, where ammonites, belemnites, brachiopods and foraminifera are very abundant under transgressive conditions (Gómez and Goy, 2005).

One of the first cited extinction mechanisms in the Iberian Range was the development of low oxygen conditions (Whatley et al., 1994; Arias, 1997). Although the three sections considered in the present work didn't yield black shale, the ostracod extinction has initially related to a major anoxic episode as characterised by the large areas of Western Europe (Jenkyns, 1988; Little and Benton, 1995). Among other potential causes, such as large flood basalt volcanism (McElwain et al., 2005; Svensen et al., 2007), thermal dissociation of gas hydrates (Beerling et al., 2002; Kemp et al., 2005, 2006; Beerling and Brentnall, 2007) or large palaeoceanographic changes were later considered (Arias, 2006a, 2007, 2009). However, the ultimate cause of events triggering the early Toarcian extinction in the Iberian Range remained ambiguous in many instances. This paper analyses the combination of two major causes of physiological stress on the ostracods: high seawater temperatures and low-oxygen levels.

\subsection{Effects of low dissolved oxygen content in water on ostracod popula- tions in the Iberian Range}

Anoxic conditions were the first triggering mechanism studied in the Iberian Range (Arias, 1997). Because the Lower Toarcian marine sedimentary record across Western European is characterised by several episodes of enhanced organic carbon burial known as "oceanic anoxic events" (OAEs) (Kemp et al., 2005; Maillot et al., 2006; Suan et al., 2008), this mechanism was initially considered. The anoxia scenario has been postulated for several other Phanerozoic environmental crises and it was a good hypothesis to test first.

Intensification and expansion of deeper oxygen minimum conditions onto the shelf have been repeatedly suggested as a cause for the reduction in diversity and abundance of ostracod populations (Peypouquet, 1977, 1980; Whatley, 1991; Boomer and Whatley, 1992; Whatley et al., 1994; Whatley, 1995; Boomer et al., 2008). The entire global marine ecosystem however, cannot become anoxic since the surface waters are equilibrated with the atmosphere. Dissolved oxygen is controlled by a series of processes, i.e. oxygen is produced in the oceanic surface layer by biological production, while that it is removed in subsurface waters by the respiration of sinking organic matter. Air-sea gas-exchange promptly equilibrates near-surface waters and the atmosphere, while subsurface oxygen declining is balanced by the transport of surface waters which are richer in oxygen into the deep part of the oceans. The result is that subsurface oxygen concentrations, and the overall partitioning of oxygen between atmosphere and ocean, are reactive to the rate of surface-to-deep ocean circulation and mixing, biological production, as well as temperature and salinity. The potential extension of oxygen minimum zones in the Iberian epicontinental seas would explain why certain groups of ostracods were distressed (e.g. the metacopines), whereas the rest of the ostracod groups suffered only small losses during the crisis.

A first approximation could be to compare whether a match existed between the episode of extinction of the metacopines and the onset of low oxygen levels in the Iberian Range. Generally, the presence of one or more positive $\delta^{13} \mathrm{C}$ excursions followed by one or more significant negative $\delta^{13} \mathrm{C}$ excursions (Jenkyns, 1988; Röhl et al., 2001; van de Schootbrugge et al., 2005) in many Tethyan and Boreal sections, usually, serves to characterise the timing of the Toarcian Oceanic Anoxic Event (TOAE), a major oceanic anoxic event which characterised the European epicontinental seas during the early Jurassic (Jenkyns et al., 2002; Suan et al., 2008). Moreover, the time-equivalence of the early Toarcian anoxia episode and the high total organic carbon (TOC) concentration is divisive in northwest European and Mediterranean sections (Wignall et al., 2005; Maillot et al., 2006; Gómez et al., 2008; Gómez and Arias, 2010). In the Iberian Range, $\delta^{13} C_{\text {bel }}$ values show a noteworthy excursion towards more negative values in the Semicelatum Subzone, Tenuicostatum Zone (Fig. 10). The rest of the Tenuicostatum Zone and the succeeding Serpentinum Zone are characterised by positive excursion values of $\delta^{13} \mathrm{C}_{\text {bel. }}$. Meanwhile $\delta^{13} \mathrm{C}_{\text {bulk }}$ shows a minimum in the ElegantulumFalciferum subzones (Gómez and Arias, 2010) (Fig. 10). The carbon isotope record of organic carbon of the Iberian Range area confirms a distinct negative excursion in the lower part of the Elegantulum Subzone. This excursion is well correlated with that around the Tenuicostatum-Falciferum zone boundary in Northwest Europe (Gómez et al., 2008; Gómez and Arias, 2010). 


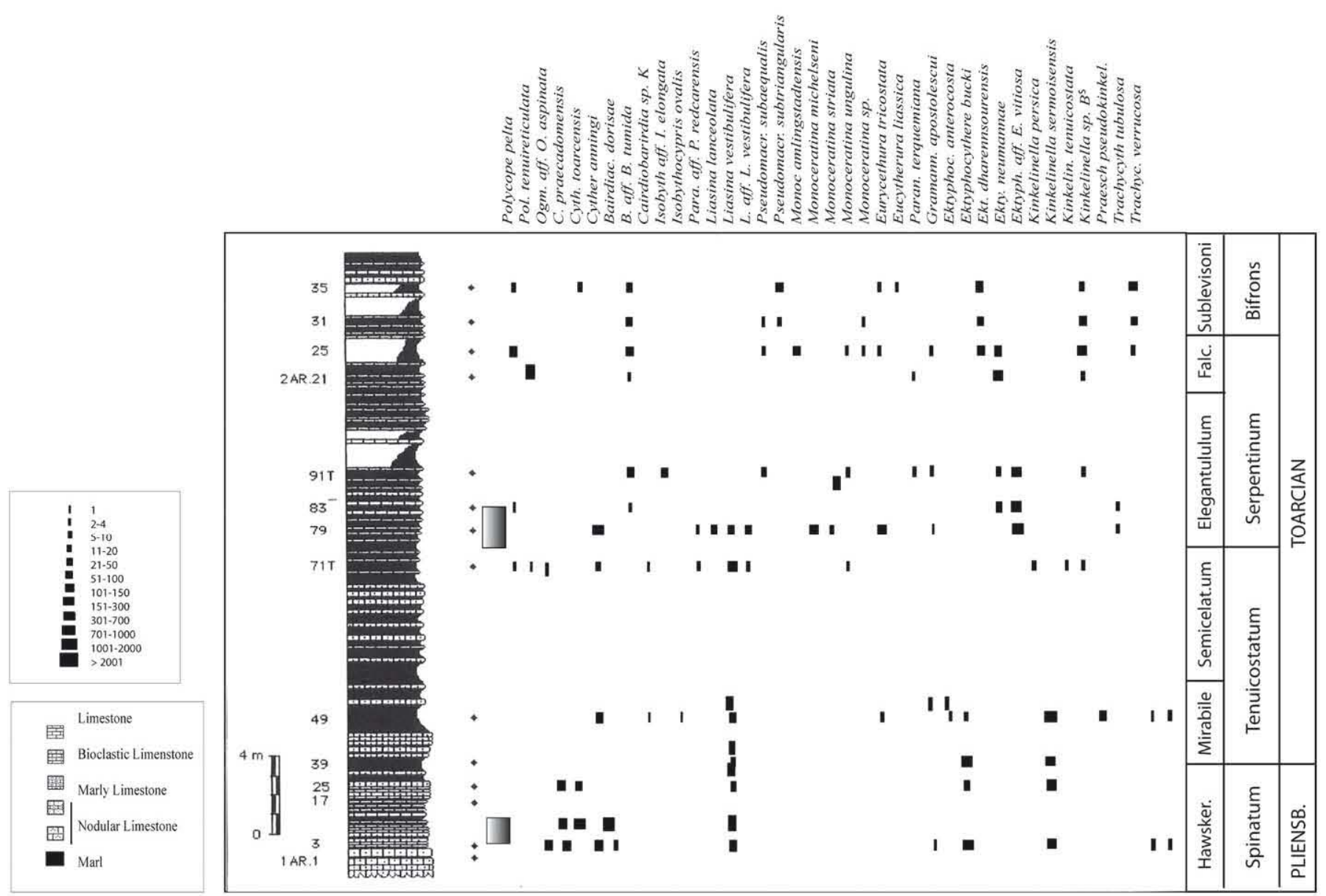

Fig. 3. Ranges of ostracod species across the Pliensbachian-Toarcian boundary depicted at the stage level at the Ariño section. Vertical bars show extinction horizons.

Although no black-shale deposits have been described in the studied area, TOC values $>1$ wt.\% and laminated deposits have been recorded in the Mirabile Subzone, Tenuicostatum Zone (Gómez and Goy, 2011), coinciding with the last records of the metacopines in many sections of the Iberian Range (Gómez and Arias, 2010; Gómez and Goy, 2011). Therefore, the disappearance of the metacopines (healdioids) in the Iberian Range seems to be coincident with low dissolved oxygen conditions in bottom water. The disappearance of healdioids is followed by their replacement first by cypridoids and then, by cytherellids.

The identification of large numbers of cytherellids (Platycopina) has been associated with the presence of low oxygen levels (Whatley, 1991; Boomer and Whatley, 1992; Whatley et al., 1994; Arias and Whatley, 2004; Boomer et al., 2008). The relationship between low oxygen concentration in the water and the numerical abundance of filter feeding ostracods (cytherellids) is based on the theory that the filter feeding strategy would allow higher ecological success during anoxic events, because during low oxygen conditions, water could circulate more easily inside the carapace (Whatley, 1991; Whatley et aL, 1994; Boomer et al., 2008). The results of this study (Fig. 9A-B) did show actually an increase in the relative abundance of the genus cytherella after the first crisis episode (Fig. 9A-B).

However, recent studies have shown further explanation about the presence of a large number of cytherellids in fossil ostracod assemblages. Dingle et al. (1989), Brandão (2008), Brandão and Horne (2009) and Horne et al. (2011) suggested that was the existence of a different water-mass structure with low salinity and deep water masses which could explain the higher numbers of platycopines (cytherellids). This last proposal would indicate that the cytherellids could have inhabited deep-intermediate waters. If the cytherellids lived in deep-intermediate waters and if they could withstand physiologically low oxygen levels, it is possible to consider that the peak of cytherellids, after the disappearance of the metacopines, could have taken place because both groups (metacopines and cytherellids) also inhabited deep waters. If they inhabited deep waters, depth or some phenomenon related to the increase of depth would have acted. Temperature and oxygen content would again be cited. The metacopines might not have been able to cope with such low oxygen levels while the cytherellids could.

Thus, another important aspect would be the change of water temperature in the European epicontinental seas (EES) at the beginning of the early Toarcian. One new approach related to the previous paragraph is the oxygen limited thermal tolerance of the metacopines. For many marine organisms, metabolic oxygen demand augments with increasing temperature, and inflicts thermal limits on survival when it exceeds the rate at which oxygen can be supplied from the medium (Pörtner, 2010). Based on this thought, the metacopine would have been most affected because its oxygen-limited thermal tolerance does not allow them to meet their needs for oxygen.

Dissolved oxygen status also influences the uptake or release of nutrients from sediment. When oxygen is depleted more nutrients (e.g. nitrogen and phosphorous) are released from the sediment and can be absorbed, transported and utilised physiologically by organisms. These nutrients therefore continue to deliver organic matter to the ocean sediments. With organic matter removed from invertebrate consumption to microbial decomposition, opportunistic species would be favoured (Nelson et al., 1994; Diaz and Solow, 1999). Related to this phenomenon, Horne et al. (2011) proposed a new alternative interpretation for the dominance of platycopids (cytherellids) in ostracod assemblages from the Cenomanian to Turonian boundary sediments from 


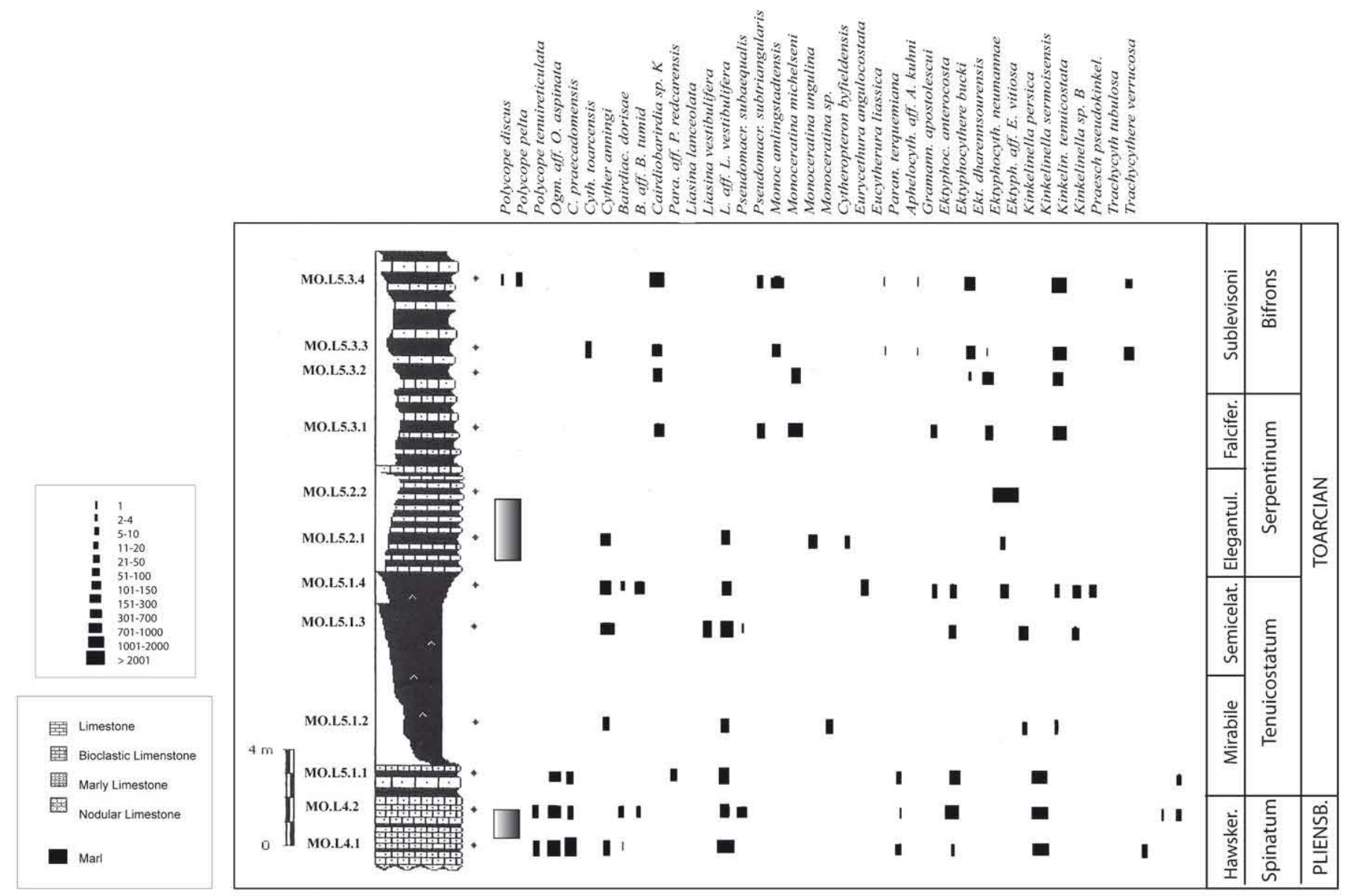

Fig. 4. Ranges of ostracod species across the Pliensbachian-Toarcian boundary depicted at the stage level at the Moneva section. Vertical bars show extinction horizons.

southern England. They related the domination of platycopids with significant oligotrophic conditions, because living platycopids appear to be adapted to filter-feed on nano- and picoplankton which are predominant in oligotrophic conditions. Thus, ocean stratification, during an oceanic anoxic episode (e.g. T-OAE) would have promoted oligotrophic conditions in surface warming waters (during the early Toarcian) and maximum diversity of larger cytherellids. Thus the low amount of oxygen and/or nutrients in the medium would have favoured to the cytherellid populations against the metacopine populations.

However metacopines were able to escape from stressful environmental situations such as periods of anoxia during the Jurassic. What factors might prevent one from seeking more appropriate areas for their survival? The metacopines might have been unable to migrate to other areas due to palaeogeographic restrictions, changes in the distribution of water bodies, competition with other ostracod groups, or perhaps the geographical extent of oxygen minimum conditions in the deep sea was so great during the Toarcian that they were not able to escape the more oxygenated areas. In this paper two motives are proposed: the deep water structure in the epicontinental seas of Europe and the sudden massive increase in temperatures in the northern areas of the EES that prevented them to find areas with warm temperatures where to live.

Anoxia is found in areas that have restricted water exchange by a physical barrier or by a pronounced density stratification (Struck et al., 2001; Casford et al., 2003). Palaeoceanographic reconstruction for the late Pliensbachian and early Toarcian in the Iberian epicontinental sea, a semi-enclosed embayment isolated from the Tethys Ocean by a narrow, shallow sill, has shown that it is characterised by a marginal sea-like oceanographic regime (Ziegler, 1990, 1992; Arias, 2007, 2008b). This marginal sea would be characterised by a well-stratified two layer structure (Fig. 11a,b) in the water column made up of a surface layer and a bottom layer that are separated by a strong pycnocline (Arias, 2007, 2008b). During the late Pliensbachian, epicontinental seas in the Iberian area operated as a shallow estuary (Fig. 11c), that could have favoured a significant stratification and the formation of low oxygen levels in bottom waters below the mixed layer under several palaeoceanographic conditions, for example the sapropel formation under anti-estuarine circulation conditions in the Mediterranean Sea (Struck et al., 2001; Casford et al., 2003). At the beginning of the Toarcian the climatic conditions changed (Chandler et al., 1992) and new warming conditions dominated the Iberian Range seas (Arias, 2006a, 2007, 2008b; Gómez and Arias, 2010), generating: (i) a weaker anti-estuarine circulation driven by intense buoyancy loss at the surface (by the strong evaporation), (ii) an important deep water formation, (iii) an inflow of relatively freshwater surface water with low nutrient content (Fig. 11), (iv) the reduced deep ventilation, and (v) low oxygen conditions (Struck et al., 2001; Casford et al., 2003). Thus, this model would explain a return to more oxygen-rich conditions in the Iberian Range during the early Toarcian.

This model shows a well-oxygenated surface layer, whereas at the pycnocline, the dissolved oxygen declines sharply reaching dysoxic or even anoxic condition in the deep. The upper metres of the epicontinental sea would be generally well oxygenated due to the gas diffusion from the atmosphere, agitation of the seawater by wind action and transport of oxygenated waters by shallow water. These areas would therefore allow the survival of many benthic taxa living in shallow shelf waters that were oxygenated. The stratified waters would support ostracods in the oxygenated surface layer but the deeper layers became a lethal mixture where life was impossible. Following the palaeoceanographic model, only shallow or intermediate 


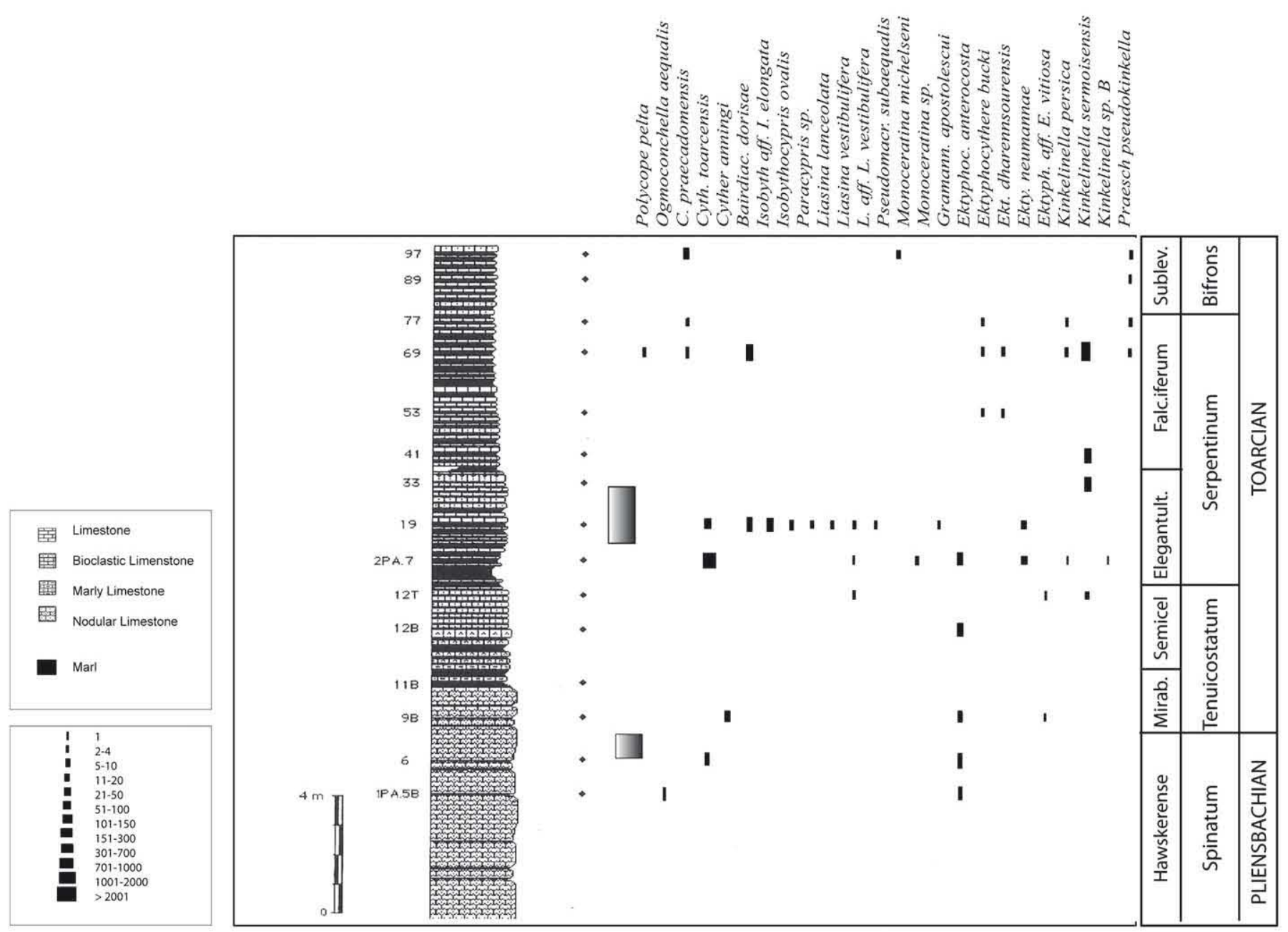

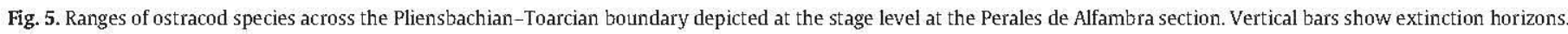

water ostracods would be able to survive; meanwhile deeper water ostracods suffered the low-oxygen conditions. Since the metacopines were the only ones who did not survive, they might have inhabited these deeper habitats, at least during the weak oxygen crisis in the Iberian Range, while cytheroids, bairdioids, cypridoids and polycopids could inhabit shallower oxygen-rich waters. Cytherellids could have shared with metacopines deep sea areas, but they were by their physiology more resistant to low oxygen conditions.

As bathymetric restrictions of these species are unknown, the proposal cannot be proved and will only be trying to find new methods of the study. In an attempt to relate palaeobiogeographical distribution patterns of 274 Early Jurassic ostracod species from the Boreal and Tethyan provinces of the European-Western Tethys region to three major marine facies associations in the European area, Arias (2006b) recognised the following assemblages: (1) A Tethyan fauna located between $35^{\circ} \mathrm{N}$ and $35^{\circ} \mathrm{S}$ of latitude (normal salinity and warm water conditions). It is characterised by the presence of smooth-shelled bairdioids, ornamented healdioids and some small cytheroids; (2) A Boreal-European fauna, mainly located above $35^{\circ} \mathrm{N}$ (high salinity and warm water conditions) characterised by the presence of very few metacopines (though common and diverse in this region, many of them are large) and thick-shelled cytheroids and cytherellids; (3) an Arctic-Boreal fauna dominating the northern part of the EES, inhabiting deeper environments (e.g. marine shales and/or clastic sediments from Western Irish basins). It is characterised by low diversity assemblages dominated by mainly smooth healdioids, some small cytheroids and some bairdioids. The presence of the large smooth healdioids in all deep-water assemblages would indicate that many species of healdioids could have been lived in deep shelf environments.

Another factor that must be considered is the physiology of the metacopines. The early Toarcian extinction could have been a physiological crisis in that the selection was largely controlled by the respiratory capability of the involved groups. If the connection between the major ostracod groups is analysed, the disappearance of the metacopines would significantly change the relationships between all groups (Figs. 6 ; 9A-B). Late Pliensbachian assemblages in the Iberian Range are dominated by healdioids and cytheroids. After the disappearance of the healdioids, cytheroids and after that, bairdioids first and then cytherellids dominate ostracod assemblages in the Tenuicostatum Zone (Fig. 9A-B). The Serpentinum and earliest Bifrons zones are dominated again by cytheroids. Arias (2008a), Boomer et al. (2008) and Arias and Whatley (2009) considered the possible existence of some competition between the ostracod groups, so that the extinction of the metacopines after a major environmental change (low oxygen conditions) would have resulted in the occupation of niches that had been vacated by other groups. First these new habitats would be occupied by opportunistic organisms (bairdioids, cypridoids, and cytherellids) which could withstand oxygen-poor conditions, and then they would be replaced by generalist species (cytheroids). The replacement between groups could represent the colonisation of the area after environmental perturbation and the disappearance of the metacopines. 


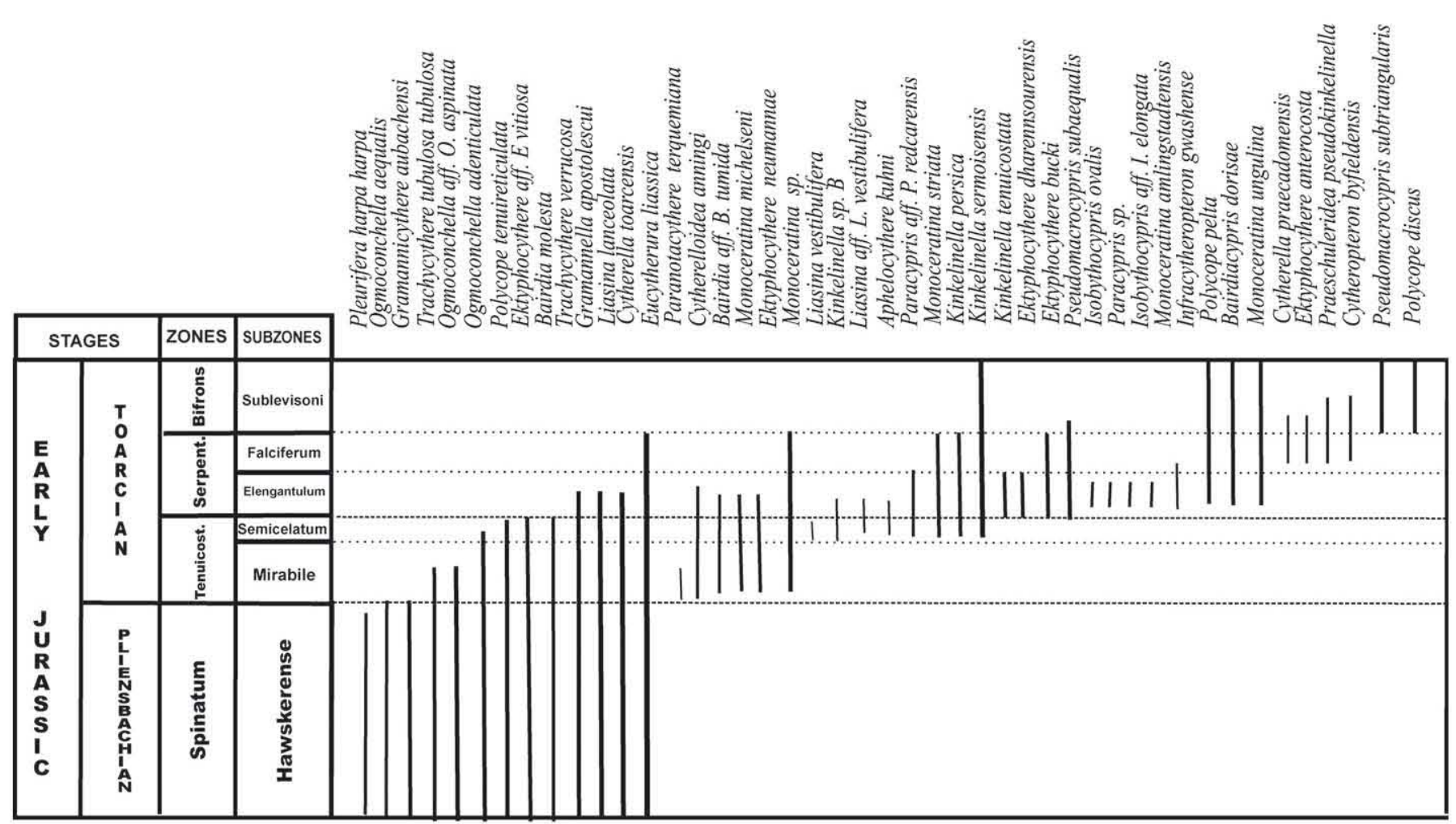

Fig. 6. Stratigraphic section and ostracod species range chart for the early Toarcian of the Iberian Range.

\subsection{The effect of seawater temperature change on the extinction of ostracods}

Another mechanism of extinction that has been argued to be most compatible with the observed ecological pattern of selectivity described among ostracod assemblages in the Iberian Range during the Toarcian crisis is related to changing climatic conditions (Arias, 2007; Gómez and Arias, 2010). Early Jurassic climate models reveal an Earth warmer than at present with a latitudinal temperature gradient dominated by high-latitude warming and slight tropical change (Arias, 2000; Arias and Whatley, 2005; Arias, 2007). Western Pangaea (the area closest to the Iberian Range) would be arid excluding the Tethys coast (Chandler et al, 1992). Arias and Whatley (2004) proposed that the early Toarcian ostracod turnover could be a consequence of a gradual climate change during the Pliensbachian-Toarcian boundary from cold to warm seas. Early Toarcian climate models (Chandler et al., 1992) seem to indicate that tropical sea surface temperatures were higher than today (from $25{ }^{\circ} \mathrm{C}$ in the East Panthalassa Ocean to $32{ }^{\circ} \mathrm{C}$ in the West Tethys Ocean). High-latitude sea surface temperatures were much lower (seasonal range from $3.5^{\circ} \mathrm{C}$ to $9.5^{\circ} \mathrm{C}$ ) and the equator-to-pole temperature gradient was much lower than today (Chandler et al., 1992). In this scenario increased water temperatures in the central and northern Europe could have had tragic results for the ostracod faunas inhabiting these areas.

In support of this warm temperature scenario, the results of the analysis of oxygen isotopes $\left(\delta^{18} \mathrm{O}\right.$ belemnites) reveal a long term shift towards more negative values from the Upper Pliensbachian to the Elegantulum Subzone, Serpentinum Zone, Lower Toarcian (Fig. 12). The isotopic record in the Iberian Range fluctuates between about -0.29 (\% PDB) at the Apyrenum-Hawskerense subzone transition and about $-2(\%$ PDB) at the Tenuicostatum-Serpentinum zone transition. Calculated temperatures using the equation of Anderson and Arthur (1983) reveal a long-term gradual temperature change of $4^{\circ}-7{ }^{\circ} \mathrm{C}$, with values oscillating between about $9.2^{\circ} \mathrm{C}$ at the beginning of the Hawskerense subzone and $17{ }^{\circ} \mathrm{C}$ at the TenuicostatumSerpentinum zone boundary (Comas-Rengifo et al., 2010; Gómez and Arias, 2010). Thus, seawater temperature (in the water column where belemnites lived) varies from a colder scenario at the PliensbachianToarcian boundary to substantially increased thermal conditions in the Elegantulum Subzone at the beginning of the Serpentinum Zone (Rosales et al., 2004; Gómez and Arias, 2010).

Another type of information which would support the existence of this new warming period is the study of stable isotopes of carbon (Fig. 10) in the Iberian Range (Gómez and Arias, 2010). The resultant belemnite $\left(\delta^{13} \mathrm{C}_{\text {bel }}\right)$ curve provides a main positive excursion from the lower Tenuicostatum Zone to the Falciferum Subzone, Serpentinum Zone where the trend changes, which becomes negative until the upper Bifrons Zone in the La Almunia de Doña Godina section. In the Sierra Palomera section, $\delta^{13} C_{\text {bel }}$ records a well defined positive excursion within the Mirabile Subzone, Tenuicostatum Zone, changing this trend towards increasing to Bifrons Zone. The $\delta^{13} \mathrm{C}_{\text {bulk }}$ values also describe a significant positive excursion, which is more evident in the carbonates of the Sierra Palomera section. Within the positive excursion, a negative $\delta^{13} \mathrm{C}_{\text {bulk }}$ shift has been recorded in both sections, but at Sierra Palomera this developed from the beginning of the Serpentinum Zone to the lower half of the Elegantulum Subzone, while at La Almunia de Doña Godina the onset of the negative shift occurs slightly later and extends along the Elegantulum Zone.

Several hypotheses have been proposed to explain this perturbation, but the input of large quantities of isotopically light $\left({ }^{12} \mathrm{C}\right)$ methane from the thermal dissociation of gas hydrates buried in marine sediments is one hypothesis (Hesselbo et al., 2000; Kemp et al., 2005, 2006; Cohen and Coe, 2007; Suan et al., 2008; Dickens, 2011). An alternative explanation or extra-source of light carbon should have biomass burning (Kurtz et al., 2003; Finkelstein et al., 2006). The Lower Toarcian black shales, type II kerogen which is a mixture of the alginite and bituminite macerals (Littke et al., 1988) of Central and Northern Europe could have suffered fires or spontaneous combustion and the additional emission of carbon dioxide would have contributed to the action of other proposed mechanisms. Clearly this discussion is beyond the scope of this paper, but it is interesting because most of these hypotheses point to an episode of very sharp increase in sea temperatures. In the Iberian Range sections, the $\delta^{13} \mathrm{C}_{\text {bulk }}$ 


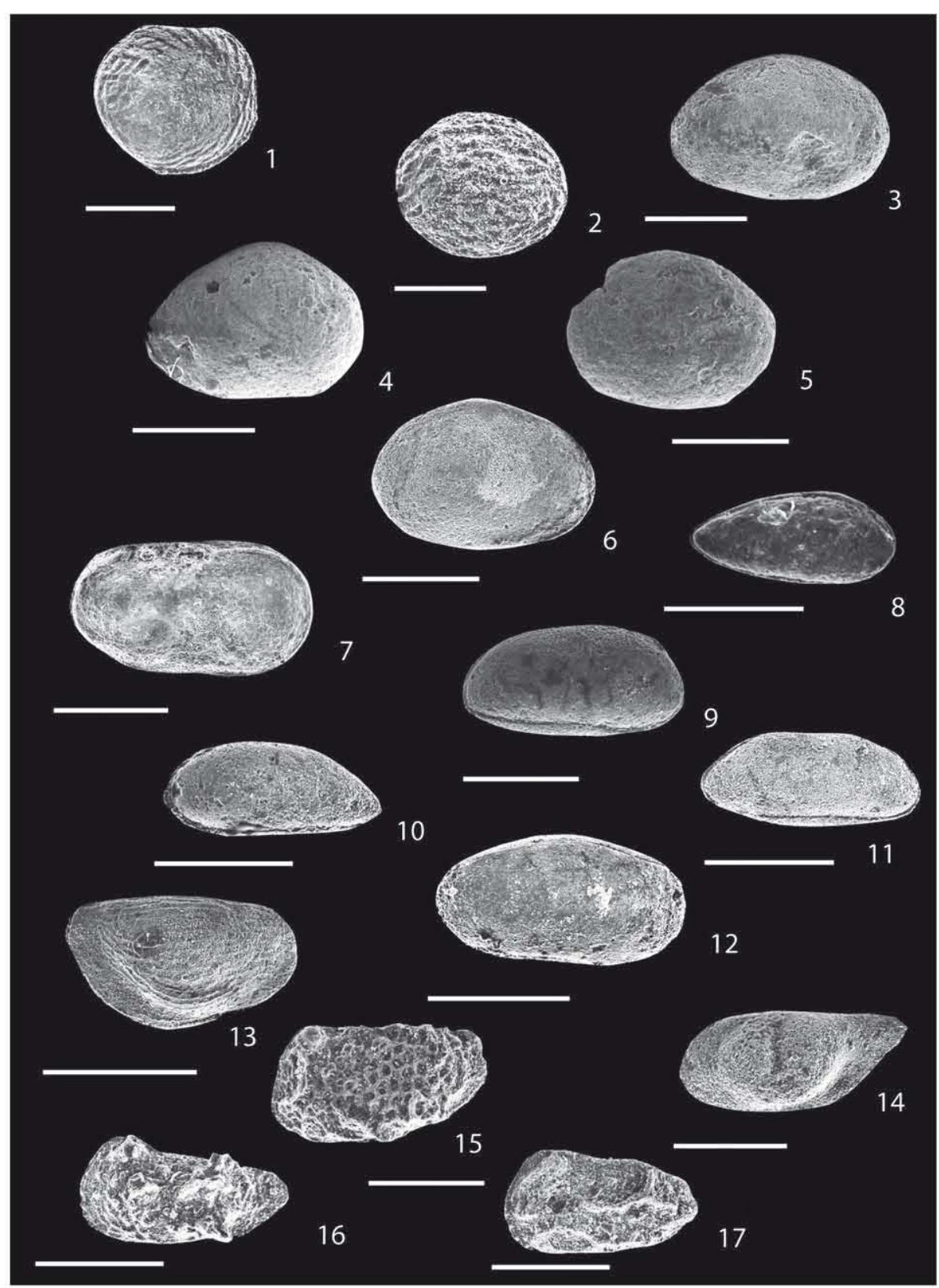

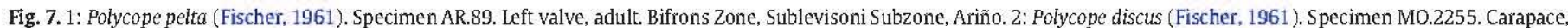

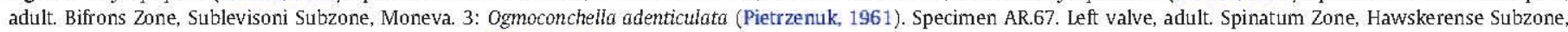

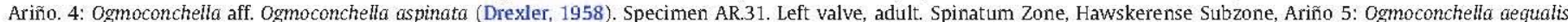

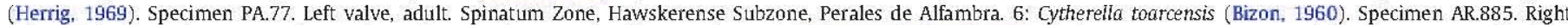

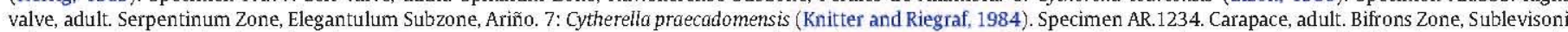

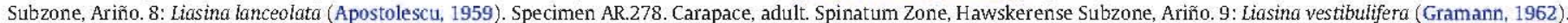

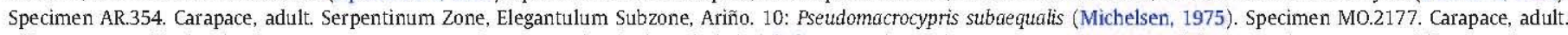

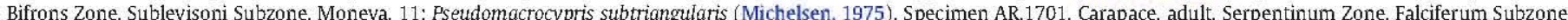

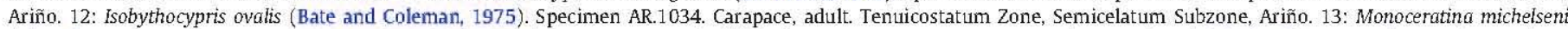

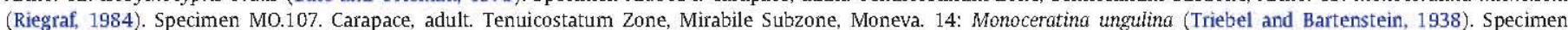

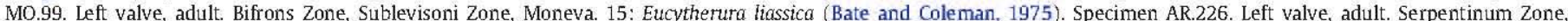
Falciferum Subzone, Ariño. Scale bars $=100 \mu \mathrm{m}$ long.

record shows negative excursions in the beginning of the Elegantulum Subzone, Serpentinum Zone (Gómez and Goy, 2011). Thus, at the beginning of the Toarcian, the climatic scenario changed and an increase of seawater temperatures (from $12{ }^{\circ} \mathrm{C}$ up to $19.5{ }^{\circ} \mathrm{C}$ ) from the Tenuicostatum Zone to the Serpentinum Zone took place in the Iberian Range (Gómez and Arias, 2010).

According to all these data, the significant late Pliensbachian cooling episode could have affected warm ecosystems (e.g. Tethys area) as species inhabiting these regions have no refuge against colder conditions because of the ocean currents in the EES and in the western corner of the Tethys Ocean (Arias, 2008b). The palaeoceanographic model for the EES and western part of the Tethys Ocean follows an estuarine-anti-estuarine circulation evolution consequence of an alternation of humid and cold conditions dominated (reduced salinity) and warm conditions with high evaporation rates (increased salinity). These climatic variations caused an estuarine 


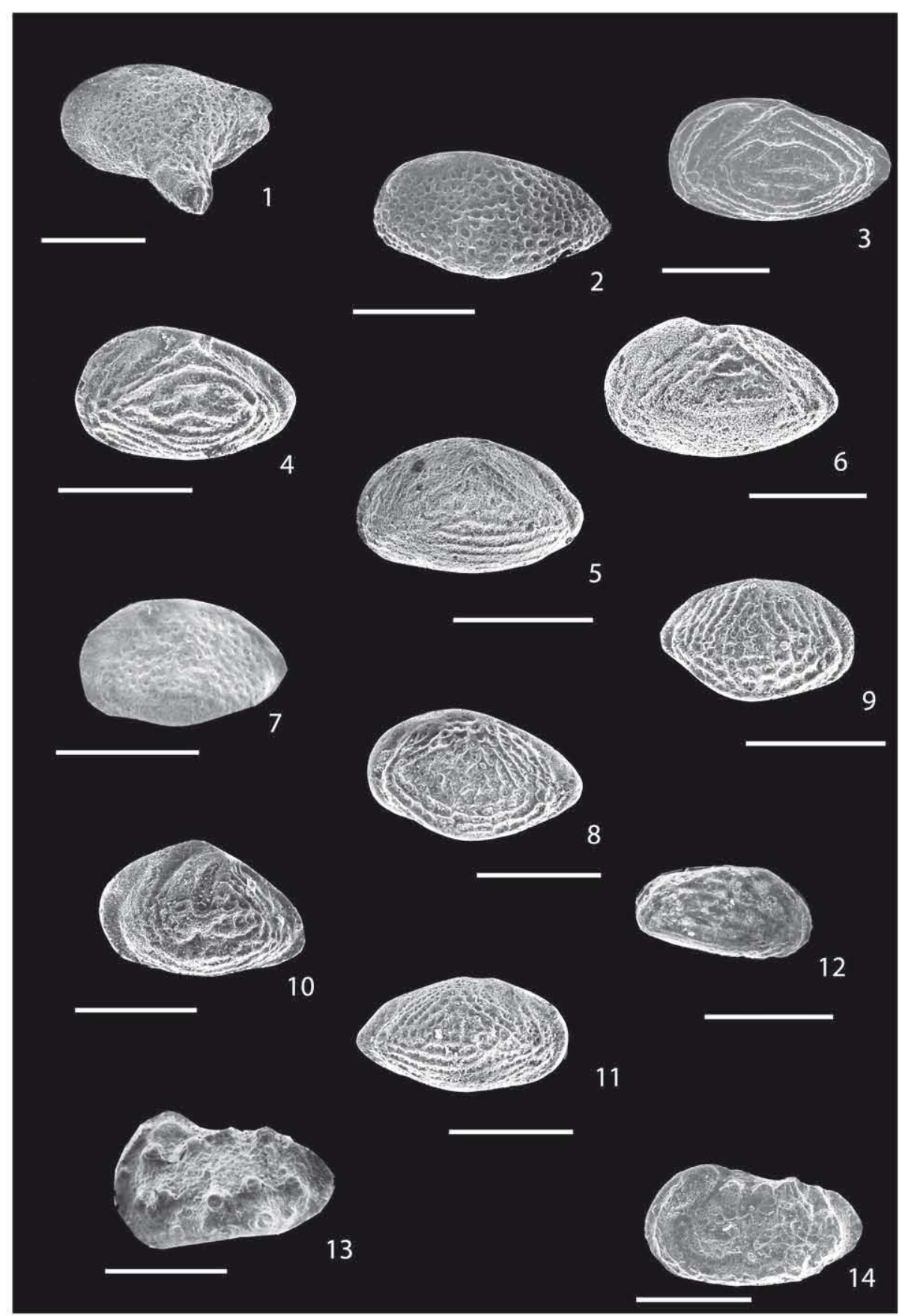

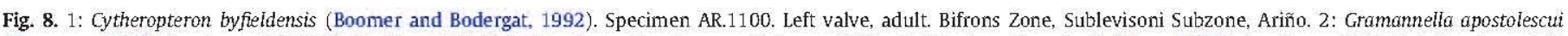

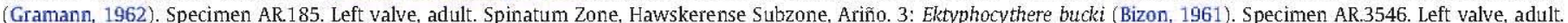

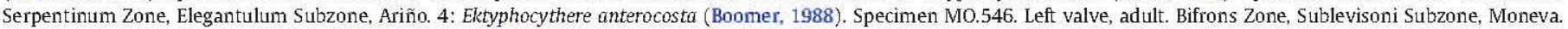

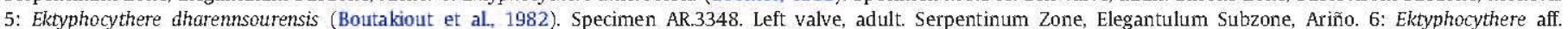

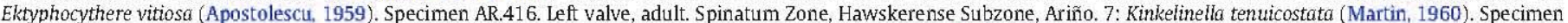

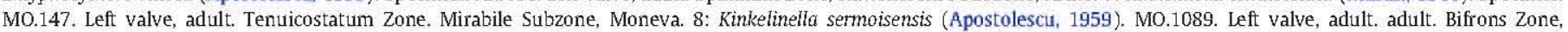

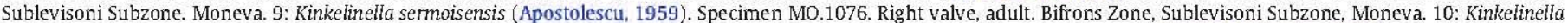

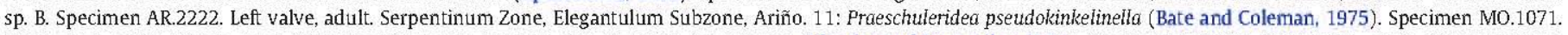

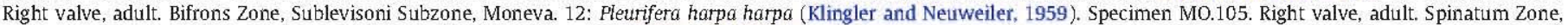

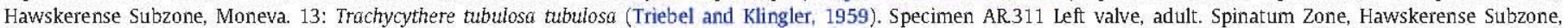
Ariño. 14: Paranotacythere terquemiana (Jones, 1872). Specimen AR.667. Left valve, adult. Tenuicostatum Zone, Mirabile Subzone, Ariño. Scale bars = 100 $\mu \mathrm{m}$ long.

circulation in the late Pliensbachian and an anti-estuarine circulation in the early Toarcian. Under the Pliensbachian cold temperature conditions an estuarine circulation is developed (Fig. 11a): (1) Tethyan water enters into the EES and it can be dense enough to sink down to the bottom of the basin, displacing water already there, but sometimes these water masses are not sufficiently dense to displace the deep waters, and travels up the EES at intermediate depths;
(2) from the south-western to north-eastern EES, there are several separate layers of water, sandwiched by a zone of mixing with a different movement of the most saline water towards the northern margin of the EES, while the less saline water moves in the opposite direction towards the southern margin of the EES; and (3) in the northern parts of the EES, under the trade wind belt, originates a north-westward drift of surface waters into the Tethys Ocean. Thus, ocean surface 

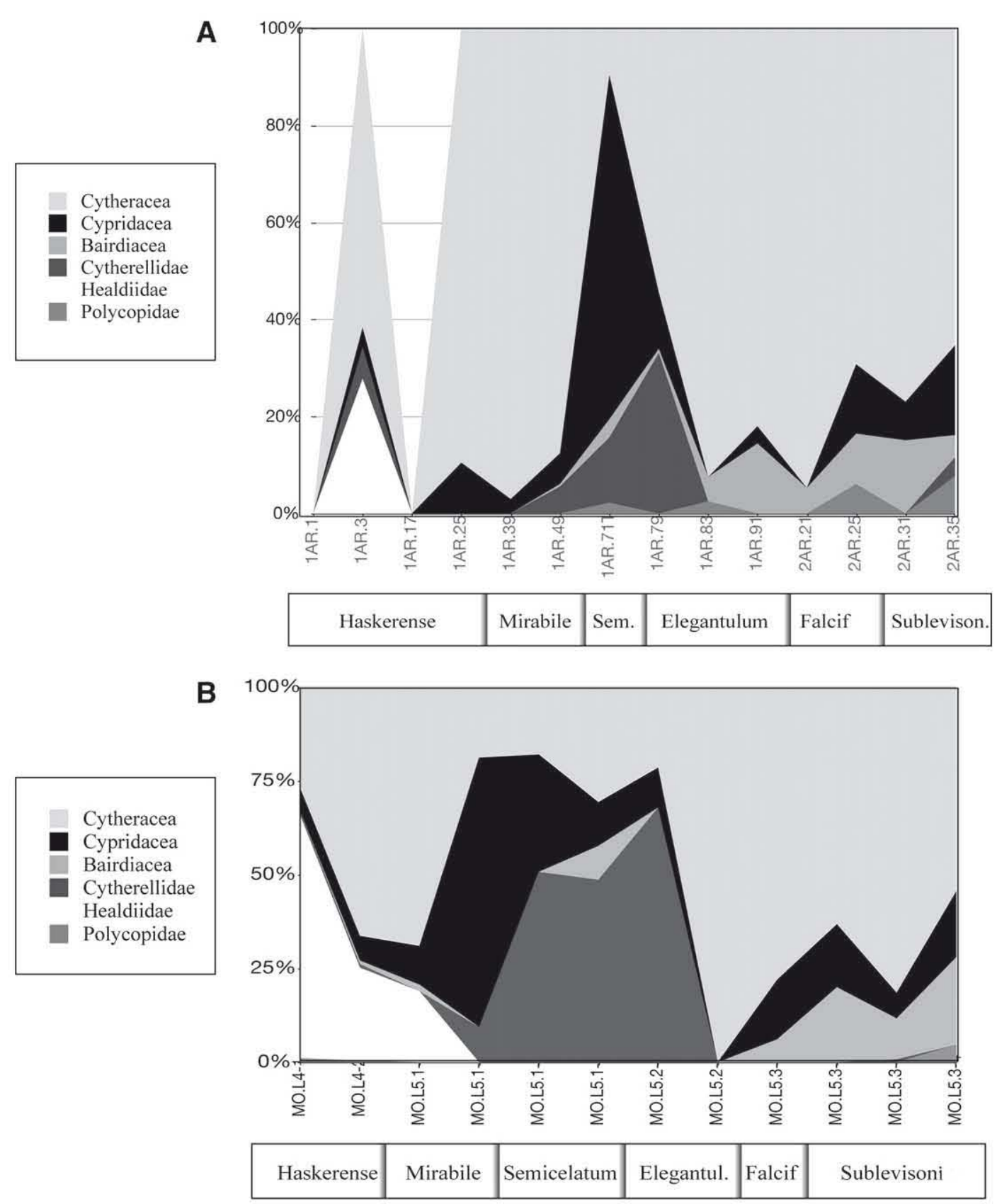

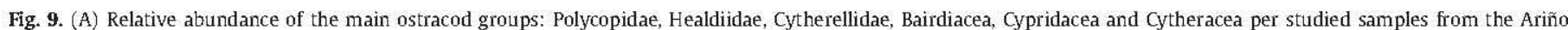

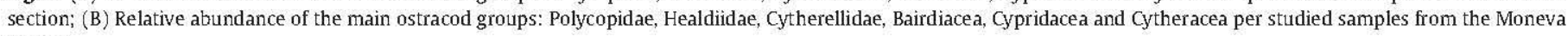
section.

currents track a leading northeast-southwest direction during the late Pliensbachian (Arias, 2007).

Middle-latitude ecosystems would be less affected since many species could simply migrate to equatorial latitudes, thus maintaining their temperature tolerance ranges (EES). Since the late Pliensbachian ostracod assemblages in the Iberian Range are dominated by metacopines and large cytheroids (Figs. 3-5, 6). When drawn migration movements of some of the most significant late Pliensbachian species it can be seen as many of the Tethyan ostracod enter via the southern parts of central Europe and move from southern Germany to the Iberian Range shelf seas (Arias and Whatley, 2004, 2005; Arias, 2006b). Thus, ostracods living in warmer waters of the Tethys Ocean were able to survive in the mild waters of the southern EES during the late Pliensbachian and they later moved to warmer areas in the EES because of the change on the ocean circulation during the early Toarcian.
At the beginning of the Toarcian the climatic conditions have changed, and greenhouse warming conditions came to dominate the EES. Warm conditions result in a buoyancy loss and a weaker antiestuarine circulation involving an inflow of Tethyan surface water and an outflow of denser EES water, which reached the central basins of the EES (Fig. 11b). Ocean surface circulation would follow an anticlockwise movement in the eastern side of the EES, with a leading northeastsouthwest direction (Arias, 2007).

Arias $(2007,2009)$ reviewed the palaeobiogeographical distribution of two hundred and seventy four ostracod species worldwide, to establish possible migration pathways between the northern and southern parts of the EES from the late Pliensbachian to early Toarcian (Fig. 13A-B). During the late Pliensbachian, the metacopines entered the EES through the straits located in the southern parts of the EES and spread out along the entire epicontinental sea (Fig. 13A, 


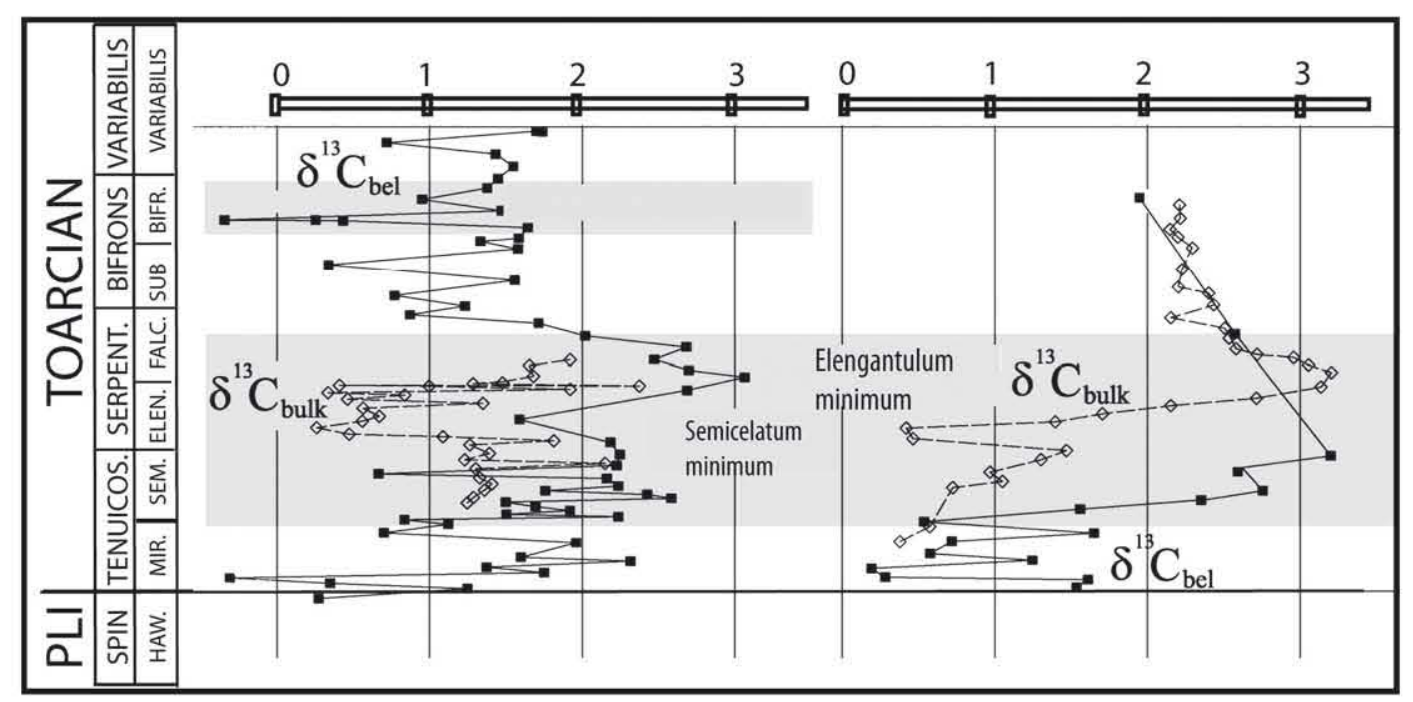

Fig. 10. Chart showing the composite $\delta^{13} \mathrm{C}$ curves obtained from belemnite calcite samples $\left(\delta^{13} \mathrm{C}_{\mathrm{bel}}\right)$ and bulk carbonates $\left(\delta^{13} \mathrm{C}_{\mathrm{bulk}}\right)$ from the Lower Jurassic sediments of the Iberian Range. Left curve La Almunia de Doña Godina section, Right curve Sierra Palomera section. The shaded areas represent minimum values in the value of the isotopes of carbon. Results have been plotted with respect to ammonite zones and subzones (Gómez and Arias, 2010).

deep water arrow); meanwhile the cytherellids followed a route from the southwestern to northeastern parts of the EES (Fig. 13A, intermediate water arrow). Cypridoids and bairdioids migrated in an opposite direction to the metacopines (Fig. 13B). Large and small cytheroids extended southwards from the northern parts of the EES to the
Iberian basins (Fig. 13B). Analysing the migration routes of the late Pliensbachian ostracods, it seems that healdioids and cytherellids spread northwards to the epicontinental sea, while bairdioids, cypridoids and cytheroids moved in the opposite direction (Fig. 13A, B). Perhaps some of these first groups (metacopines and large cytherellids)

A

B

\section{European Epicontinental Sea Tethys}

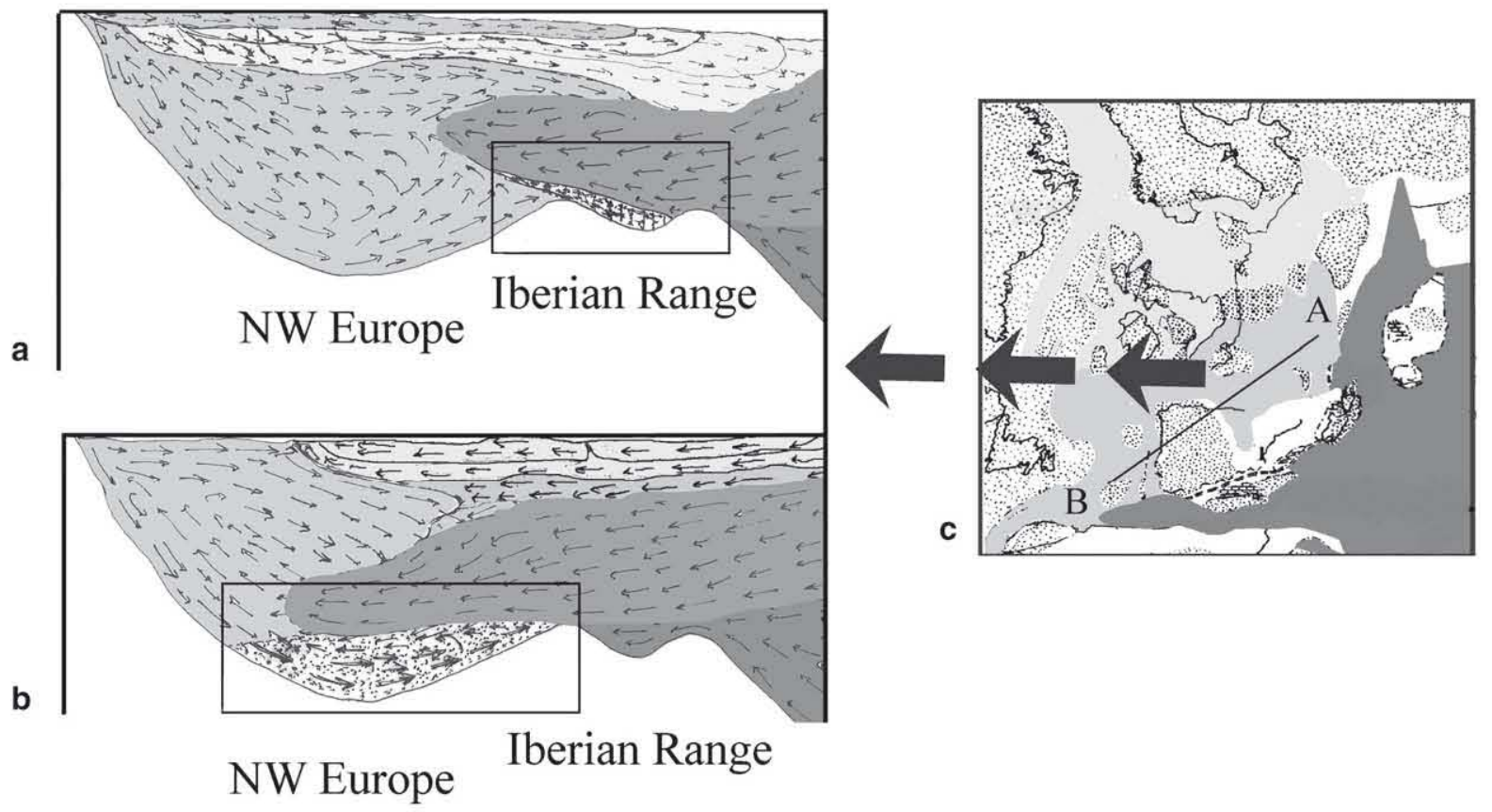

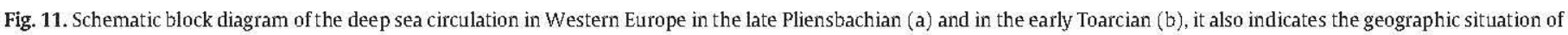

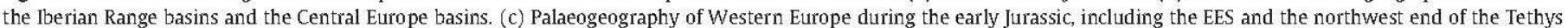

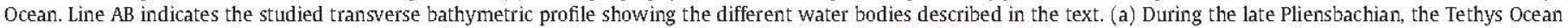

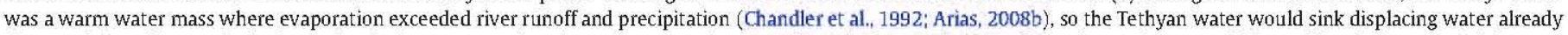

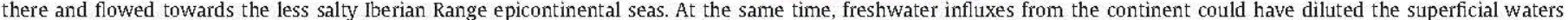

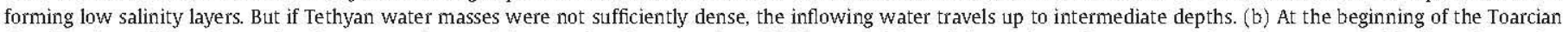

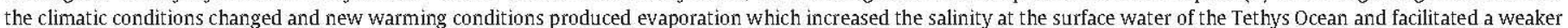

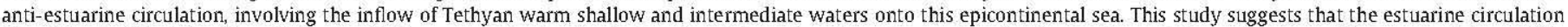

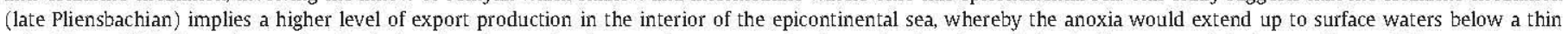

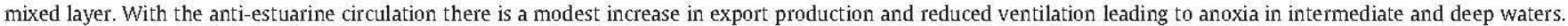




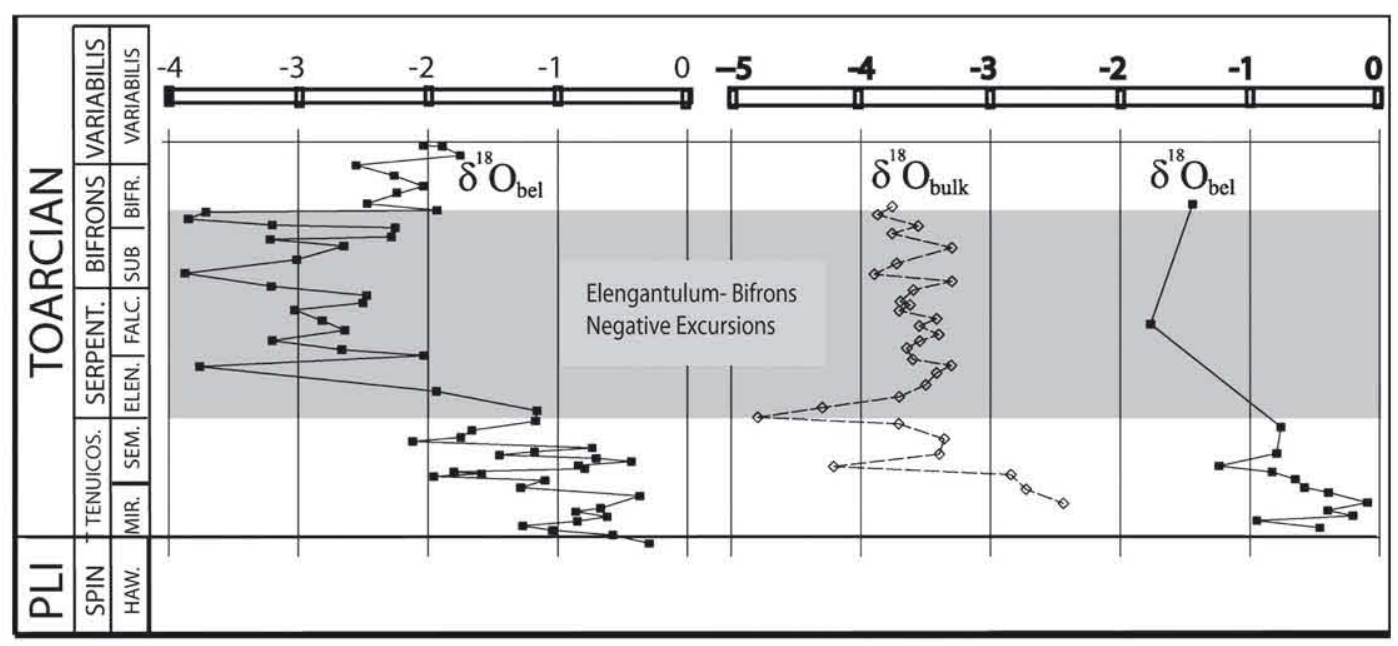

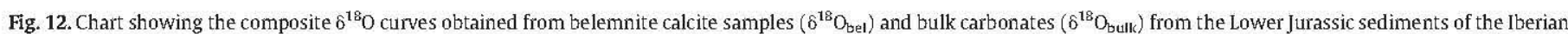

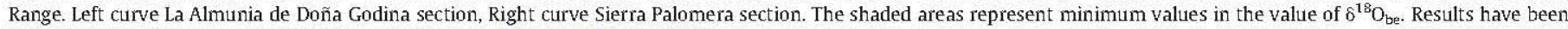
plotted with respect to ammonite zones and subzones (Gómez and Arias, 2010).

lived in temperate seas, whereas small cytheroids, bairdioids, cypridoids and polycopids might have preferred warmer seawater temperatures and moved southwards. Metacopines were capable to move to warmer waters after the cooling episode during the late Pliensbachian. The location of the Iberian Range, at the southern part of the EES, would indicate that the Iberian seas could have enjoyed warmer temperatures, hence the important movement of species to the Iberian Range.

Toarcian thermal maximum also explains as many significant ostracod species migrate northwards into the EES during the Toarcian (Fig. 13C, D). Cytherellids (Fig. 13C, intermediate water arrow), bairdioids and cypridoids (Fig. 13D) expanded northwards across the entire EES during the early Toarcian also looking for more suitable habitats. However, they suffered significant losses perhaps the water temperature was excessive and affected reproduction or food sources. If the pattern of distribution of the cytheroids is analysed, they show a northwards and southwards movement across the entire EES. They suffered a low level of extinction, but not to the same extent as the rest of the groups in the Elegantulum Subzone, Serpentinum Zone, since they lived in very shallow surface waters and might have certain physiological advantages for survival under moderate temperatures (as when they lived in the Pliensbachian cold sea), or because they might have moved to less warm places where they could have survived (Fig. 13C).

If the pattern of movement of the major ostracod groups (Fig. 13C-D) is observed during the early Toarcian, many of the ostracod groups can be seen to have entered into the Iberian epicontinental sea from the Tethys Ocean. Many of them moved northwards, meanwhile others penetrated via the southern part of the EES and then spread out northwards and southwards. This was the case of the metacopines during the beginning of the Toarcian. Its pattern of migration shows as its habitat became fragmented, with population restricted to a few areas such as the Iberian Range, British Island or some French and German basins (Arias, 2007).

Final results suggest that the majority of groups (except metacopines and cytheroids) could better withstand the higher seawater temperatures, not because of their ability to tolerate temperature, but for their ability to migrate northwards in the EES. Only cytheroids suffered changes but survived better because they were more accustomed to living in shallow water conditions, and occupied mid-latitude areas where the water temperatures during the thermal episode were not as warm (Arias, 2007). Although, they moved, they only migrated to the European central basins. That is to say that the selective survival of cytheroids that occurred during the thermal maximum (Serpentinum Zone) could be a consequence of their physiological ability to withstand high temperatures but less by their capacity to migrate to mild temperature areas. About the metacopines, their impoverished population were fragmented in particular areas of the EES that suffered the direct impact of this thermal hit and they cannot survive to this second environmental crisis. The rest of the ostracod groups suffered the change of water temperatures during the Toarcian, and their populations dropped off but they managed to move to colder areas and to survive.

\section{Conclusions}

The ostracod record of the Iberian Range demonstrates the importance of the early Toarcian ostracod extinction pattern. A total of 8510 specimens are recorded and assigned to a total of 46 species. The ostracod record illustrates two important extinction events in the Iberian Range. The first episode is characterised by the disappearance of the metacopines in the Mirabile Subzone, Tenuicostatum Zone. After this first biological crisis, the dominance of bairdioids and cypridoids, which represents the first opportunistic species, was followed by the dominance of the ostracod assemblages by platycopines (cytherellids) and then by cytheroids. The disappearance of the metacopines coincides with slightly lower levels of oxygen in the Iberian Range during a transgressive episode and at the beginning of warmer seawater temperatures in the Iberian Range. This paper analyses both the change in oxygenation conditions and of seawater temperature. The approach to this issue is that the metacopines lived in relatively well oxygenated environments. If a serious environmental crisis would have led to a drastic decline in the amount of dissolved oxygen in the deep-water masses, the metacopines, which inhabited deeper environment, might have been the most affected by these changes in the amount of dissolved oxygen in the water. The role of the seawater temperatures in this first crisis seems not to have been so important, because healdioids endure lower seawater temperatures that occurred during the late Pliensbachian. However, this first increase of the water temperature could have affected the ability of the metacopine to take oxygen from the water. Diminishing of the nutrients can also play a role in promoting the deterioration of the living conditions of the medium for metacopines.

The second episode of extinction occurs in the Elegantulum Zone, Serpentinum Zone when all ostracod assemblages suffered important losses coinciding with the end of the late Pliensbachian cooling episode and the beginning of a marked increase in water temperature in the early Toarcian. The spread of these warming conditions produced severe losses in all ostracod groups during the beginning of the Serpentinum Zone, with the only exception of the cytheroids. 
A

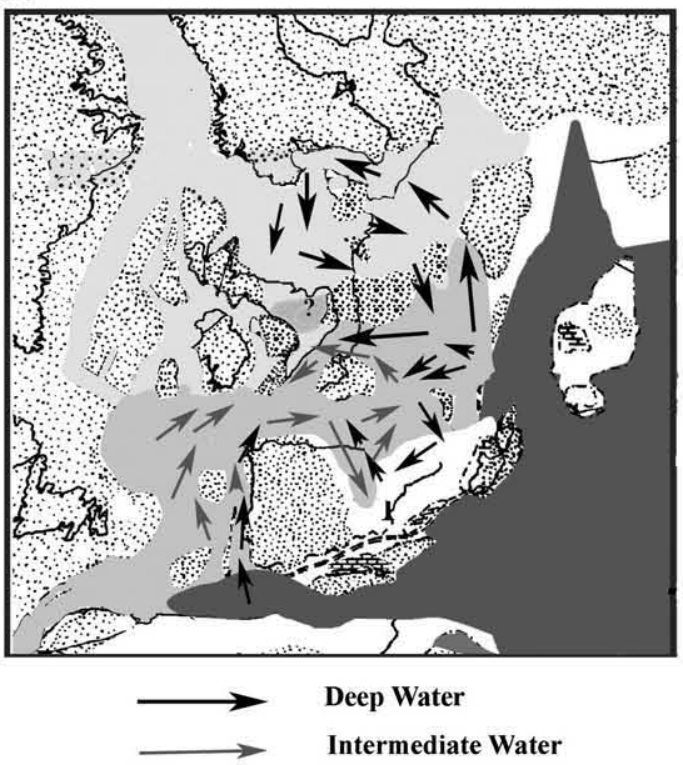

C

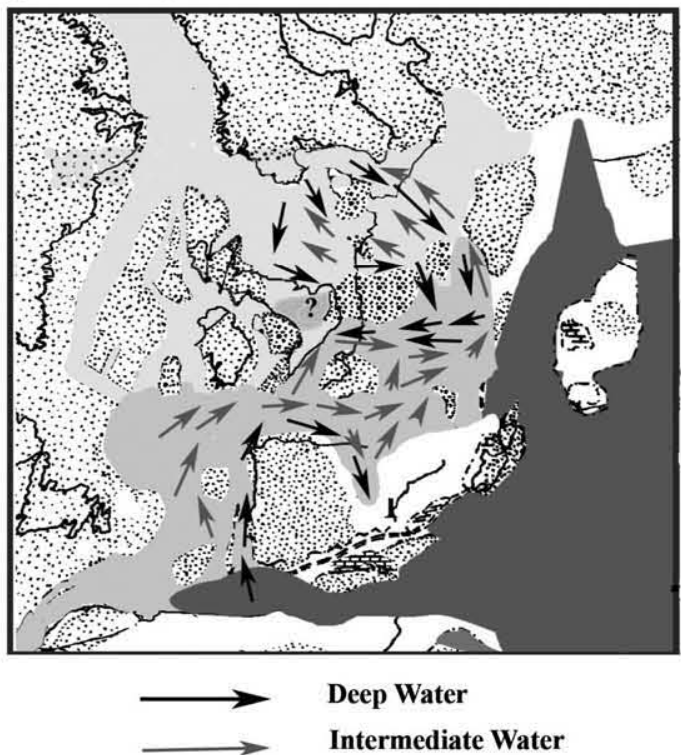

B

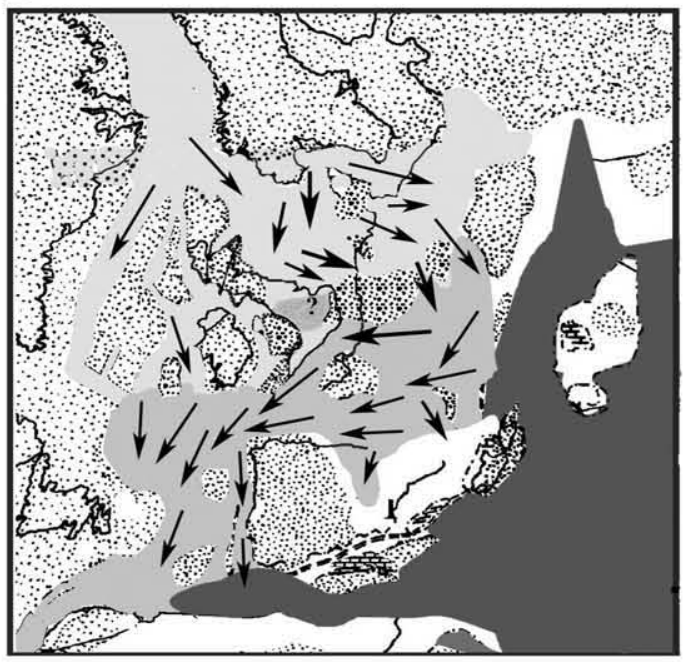

Superficial Water

D

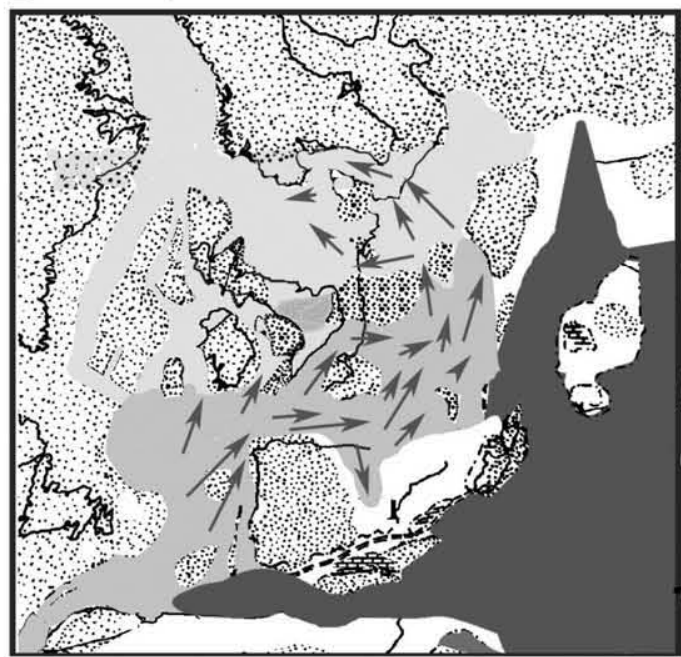

Superficial Water

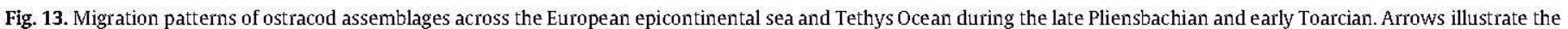

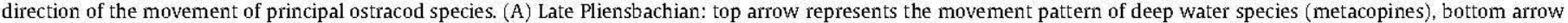

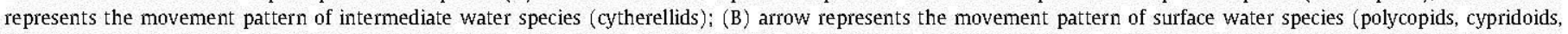

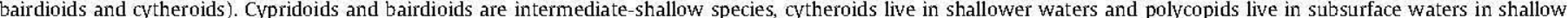

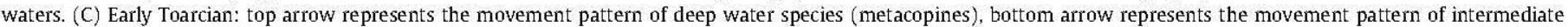

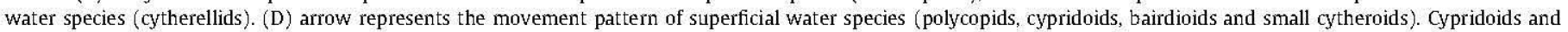
bairdioids are intermediate-shallow species, cytheroids live in shallower waters and polycopids live in subsurface waters in shallow waters.

Migration patterns show that the majority of the ostracod groups moved north to escape the higher temperatures, except cytheroids that moved to or remained in the middle latitudes with more temperate seawater temperatures.

The total process of extinction during the late Pliensbachian-early Toarcian in the Iberian Range was one major event in the history of ostracod record. Low-oxygen conditions could be responsible for the beginning of this severe extinction. Climate change contributed decisively although indirectly to both the first and the second crises, though it seems to have had a more important role during the second crisis in the Iberian Range. It was a long crisis that is reflected in the multiple changes observed in the associations of Iberian Range ostracods.

\section{Acknowledgements}

This paper is the result of my research over many years and, because so many years comprise so many people and diverse interests, my thanks is multiple. I gratefully acknowledge the helpful comments provided by Antonio Goy, Juan José Gómez, Matthias Franz and Ian Boomer during the preparation of this manuscript. Early versions of the ideas proposed in this manuscript benefited from the careful comments of Nigel Ainsworth and Alan Lord. I would also like to thank him for his help in correcting the English language of the manuscript. I gratefully acknowledge Editor Finn Surlyk, and reviewers Marie-Béatrice Forel and a second reviewer for their valuable comments and constructive reviews. I would like to express my thanks to long-term financial 
support from the Project CGL2011-25894 by the Ministerio de Ciencia e Innovación (Spain). However, the final draft was the consequence of the generous aptitude of many colleagues for the last three years. I wish finally to mention of my unforgettable friend in Aberystwyth, Robin Whatley, a good friend, well this is the last.

\section{References}

Ainsworth, N.R., 1987. Pliensbachian Ostracoda from the Fastnet Basin, offshore Southwest Ireland Bulletin of the Geological Survey of Ireland 4, 41-62.

Anderson, T.F., Arthur, M.A. 1983. Stable isotopes of oxygen and carbon and their application to sedimentologic and paleoenvironmental problems. In: Arthur, M.A., Anderson, T.F., Kaplan, I.R., Veizer, J., Land, L. (Eds.), Stable Isotopes in Sedimentary Geology. SEPM, Georgia, pp. 1-151.

Apostolescu, V., 1959. Ostracodes du Lias du bassin de Paris. Revue de l'Institut Français du Pétrole 15, 795-817.

Arias, C., 1997. Ostracod biostratigraphy of the Lower Toarcian in the Cordillera Ibérica, northern Spain. Neues Jahrbuch für Geologie und Paläontologie Abhandlungen 206, 67-91

Arias, C., 2000. The Pliensbachian-Toarcian boundary Ostracod biostratigraphy in the Cordillera Ibérica, northeastern Spain. Neues Jahrbuch für Geologie und Paläontologie Abhandlungen 216, 153-19.

Arias, C., 2006a. Northern and Southern Hemispheres ostracod palaeobiogeography during the Early Jurassic: possible migration routes. Palaeogeography, Palaeoclimatology, Palaeoecology 233, 63-95.

Arias, C, $2006 \mathrm{~b}$. Changes in ostracod provincialism during the Early Toarcian in the European Sea-Westem Tethys area. Revista Española de Micropaleontologia 38, 245-267.

Arias, C., 2007. Pliensbachian-Toarcian ostracod biogeography in NW Europe; evidence for water mass structure evolution. Palaeogeography, Palaeoclimatology, Palaeoecology 251, 398-421.

Arias, C., 2008a. Extinction pattern of marine Ostracoda across the PliensbachianToarcian boundary in the Cordillera Ibérica, NE Spain: causes and consequences. Geobios 42, 1-15.

Arias, C, 2008b. Palaeoceanography and biogeography in the Early Jurassic Panthalassa and Tethys Oceans. Gondwana Research 14, 306-315.

Arias, C., 2009. Pliensbachian ostracods from the Prejano section, Sierra de la Demanda, Cordillera Iberica. Neues Jahrbuch für Geologie und Paläontologie Abhandlungen 252, 181-206.

Arias, C., Whatley, R., 2004. Distribution patterns of Early Jurassic Ostracoda and possible communication routes across the European Epicontinental Sea: evidence changes in ocean circulation patterns and its consequence to climate change. Neues Jahrbuch für Geologie und Paläontologie Abhandlungen 232, 1-55.

Arias, C., Whatley, R.C., 2005. Palaeobiogeography of western European Lower Jurassic Ostracoda. Geobios 38, 697-724.

Arias, C., Whatley, R.C., 2009. Multivariate hierarchical analyses of Early Jurassic Ostracoda assemblages. Lethaia 42, 495-510.

Bassoullet, J.P., Poisson, A., Elmi, S., Cecca, F., Bellion, Y., Gurirand, F., Baudin, F., 1992. Mid Toarcian (184-182 m.a.). Téthys Paleomaps. In: Bassoullet, J.P., Elmi, S., Cecca, F., Le Nindre, J.Y., Manivit, J., Poisson, A. (Eds.), Paléogéographie du domaine téthysien au Toarcien. Réunion Téthys, Paris, pp. 1-19.

Bate, R.H., Coleman, B.E., 1975. Upper Lias Ostracoda from Rutland and Huntingdonshire. Bulletin of the Geological Survey of Great Britain 55, 1-42.

Beerling, D.J., Brentnall, S.J., 2007. Numerical evaluation of mechanisms driving Early Jurassic changes in global carbon cycling. Geology 35, 247-250.

Beerling, D.J., Lomas, M.R., Grocke, D.R., 2002. On the nature of methane gas-hydrate dissociation during the Toarcian and Aptian oceanic anoxic events. American journal of Science 302, 28-49.

Bizon, J.J., 1960. Sur quelques ostracodes du Lias du Bassin parisien. Revue de Micropaleontologie 2, 203-211.

Bizon, J.J., 1961. Basse-Normandie (régions d'Isigny et sur de Bayeux). In: Cousin, N., Espatilier. J., Sigal, J., Apostolescu, V. (Eds.), Colloque sur le Lias français. Mémoirs du Bureau de Recherche Géologiques et Minières, 4, pp. 431-438.

Blake, J.F., 1876. Class Crustacea. In: Tate, R., Blake, J.F. (Eds.), The Yorkshire Lias. Voorst, London, pp. 427-435.

Blakely, R., 2010. Europe-Paleogeographic Maps. Ron Blakey, Colorado Plateau Geosystems, Inc.(Database. http://cpgeosystems.com/index.html).

Boomer, I., 1988. On Ektyphocythere anterocosta sp. nov. Boomer. Stereo-Atlas of Ostracod Shells 15, 93-96.

Boomer, I., Bodergat, A.M., 1992. On Cytheropteron byfieldensis sp. nov. Boomer and Bodergat. Stereo-Atlas of Ostracod Shells 19, 1-4.

Boomer, I., Whatley, R.C., 1992. Ostracoda and dysaembia in the lower Jurassic of Wales: the reconstruction of past oxygen levels. Palaeogeography, Palaeoclimatology, Palaeoecology 99, 373-379.

Boomer, I., Lord, A., Crasquin, S., 2008. The extinction of the Metacopina (Ostracoda). Senckenbergiana Lethaea 88 (1) 47-53.

Boutakiout, M., Donze, P., Oulmach, F., 1982. Nouvelles espèces d'ostracodes du Lias moyen et supérieur du Jbel Dhar en Nsour (rides sud-rifaines, Maroc Septentrional). Revue de Micropaleontologie 25, 94-104.

Brandão, S.N., 2008. First record of a living Platycopida (Crustacea, Ostracoda) from Antarctic waters and a discussion on Cytherella serratula (Brady, 1880). In: Martínez-Arbizu, P., Brix, S. (Eds.), Bringing Light into Deep-sea Biodiversity. Zootaxa, 1866, pp. 1-574. a critical evaluation of the evidence from modern ostracod biology, ecology and depth distribution. Palaeogeography. Palaeoclimatology. Palaeoecology 283, $126-133$.

Casford, J.S.L., Rohling, E.J., Abu-Zied, R.H., Jorissen, F.J., Leng, M., Thomson, J., 2003. A dynamic concept for eastern Mediterranean circulation and oxygenation during sapropel formation. Palaeogeography, Palaeoclimatology, Palaeoecology 190. 103-119.

Chandler, M.A., Rind, D., Ruedy, R., 1992. Pangaean climate during the Early Jurassic: GGCM simulations and the sedimentary record of paleoclimate. Geological Society of America Bulletin 104, 543-559.

Cohen, A.S., Coe, A.L., 2007. The impact of the Central Atlantic Magmatic Province on climate and on $\mathrm{Sr}$ and $\mathrm{Os}$ isotope evolution of seawater. Palaeogeography, Palaeoclimatology, Palaeoecology 244, 374-390.

Comas-Rengifo, M.J., Arias, C., Gómez, J.J., Goy, A., Herrero, C., Osete, M.L., Palencia, A. 2010. A complementary section for the proposed Toarcian (Lower Jurassic) global stratotype: the Almonacid De La Cuba section (Spain). Stratigraphy and Geological Correlation 18, 133-152.

Diaz, R.J., Solow, A, 1999. Ecological and economic consequences of hypoxia, Topic 2. Report for the Integrated Assessment on Hypoxia in the Gulf of Mexico. NOAA Coastal Ocean Program Decision Analysis Series, no.16.

Dickens, G.R., 2011. Down the rabbit hole: toward appropriate discussion of methane release from gas hydrate systems during the Paleocene-Eocene thermal maximum and other past hyperthermal events. Climate of the Past 7, 831-846.

Dingle, R.V., Lord, A.R., Boomer, I.D., 1989. Ostracod faunas and water masses across the continental margin of Southwestern Africa. Marine Geology 87, 323-328.

Drexler, E., 1958. Foraminiferen und Ostracoden aus dem Lias von Siebeldingen Pfalz. Geologisches Jahrbuch 75, 475-554.

Finkelstein, D.B., Pratt, L.M., Brassell, S.C., 2006. Can biomass burning produce a globally significant carbon-isotope excursion in the sedimentary record? Earth and Planetary Science Letters 250, 501-551.

Fischer, W., 1961. Neue Arten der Ostracoden-Gattung Polycope SARS 1865 aus dem Oberen Lias (Württemberg). N. Jb. Geol. Paläont. Mh 497-501.

Gómez, J.J., Arias, C., 2010. Rapid warming and ostracod mass extinction at the Lower Toarcian (Jurassic) of central Spain. Marine Micropaleontology 74, 119-135.

Gómez, J.J., Goy, A., 2000. Sequential analysis of the Toarcian in the Northern and Central-Eastern part of the Iberian subplate (Spain), In: Hall, R.L., Smith, P.L (Eds.), Advances in Jurassic Research. GeoResearch Forum, 6, pp. 301-309.

Gómez, J.J., Goy, A., 2005. Triassic and Early Jurassic palaeogeographic evolution and depositional cycles of the Western Tethys Iberian platform system (Eastern Spain). Palaeogeography, Palaeoclimatology, Palaeoecology 222, 77-94.

Gómez, J.J., Goy, A., 2011. Warming-driven mass extinction in the Early Toarcian (Early Jurassic) of northern and central Spain. Correlation with other timeequivalent European sections. Palaeogeography, Palaeoclimatology, Palaeoecology 306, 176-195.

Gómez, J.J., Goy, A., Canales, M.L., 2008. Seawater temperature and carbon isotope variations in belemnites linked to mass extinction during the Toarcian (Early Jurassic) in Central and Northern Spain. Comparison with other European sections. Palaeogeogr. Palaeoclimatol. Palaeoecol. 258, 28-58.

Gramann, F., 1962. Extremitätenfunde an liassischen Bairdien (Ostracoden) Paläontologische Zeitschrift 36, 28-32.

Hallam, A., Wignall, P.B., 1997. Mass Extinctions and Their Aftermath. Oxford University Press $1-320$.

Herrig, E., 1969. Ostracoden aus dem Ober-Domèrien von Grimmen westlich Greifswald (Teil I). Geologie 18, 446-471.

Herrig, E, 1981. Die Ogmoconchella-Arten (Ostracoda) im Lias von Thüringen. Zeitschrift für Geologische Wissenschaften 9, 561-579

Hesselbo, S.P., Gröcke, D.R., Jenkyns, H.C., Bjerrum, C.J., Farrimond, P., Morgans-Bell, H.S., Green, O.R, 2000. Massive dissociation of gas hydrates during a Jurassic oceanic anoxic event. Nature 406, 392-395.

Home, D.J., Brandão, S.N., Slipper, I.J., 2011. The Platycopid Signal deciphered: responses of ostracod taxa to envimonmental change during the Cenomanian-Turonian Boundary Event (Late Cretaceous) in SE England. Palaeogeography, Palaeoclimatology, Palaeoecology 308, 304-312.

Jenkyns, H.C., 1988. The early Toarcian (Jurassic) anoxic event: stratigraphic, sedimentary and geochemical evidence. American Journal of Science 288, 101-151.

Jenkyns, H.C., Jones, C.E., Gröcke, D.R., Hesselbo, S.P., Parkinson, D.S., 2002. Chemostratigraphy of the Jurassic System: applications, limitations and implications for palaeoceanography. Journal of Geology of London 159, 351-378.

Jones, T.R., 1872. Appendix. On some bivalve Entomostraca from the Lias ("Infralias") of Yorkshire. Quarterly Journal of the Geological Society 28, 146-147.

Kemp, D.B., Coe, A.L., Cohen, A.S., Schwark, L, 2005. Astronomical pacing of methane release in the Early Jurassic period. Nature 437, 396-399.

Kemp, D.B., Coe, A.L., Cohen, A.S., Schwark, L., 2006. Palaeoceanography: methane release in the Early Jurassic period (Reply). Nature 441, E5-E6.

Klingler, W., Neuweiler, F., 1959. Leitende Ostracoden aus dem deutschen Lias. Geologisches Jahrbuch, A 76, 373-410.

Knitter, H., 1983. Biostratigraphische Untersuchungen mit Ostracoden im Toarcien Südentschlands. Facies 8, 213-262.

Knitter, H., Riegraf, W., 1984. Biostratigraphie (Cephalopoden, Ostracoden) des Oberen Toarcium von Blumberg Achdorf, Wutachs und Weilheim/Teck (BadenWürttemberg). Jahrbuch der Geologischen Landesamt Baden-Württemberg 26, 57-97.

Kurtz, A.C., Kump, L.R., Arthur, M.A., Zachos, J.C., Paytan, A., 2003. Early Cenozoic decoupling of the global carbon and sulphur cycles. Paleoceanography 18. 1090. 
Littke, R., Baker, D.R., Leythaeuser, D., 1988. Microscopic and sedimentologic evidence for the generation and migration of hydrocarbons in Toarcian source rocks of different maturities. Organic Geochemistry 13, 549-559.

Little, C.T., 1996. The Pliensbachian-Toarcian (Lower Jurassic) extinction event. Geological Society of America Special Papers 307, 505-512.

Little, C.T.S., Benton, M.J., 1995. Early Jurassic mass extinction: a global long-term event. Geology 23, 495-498.

Lord, A., 1974. Ostracods from the Domerian and Toarcian of England. Paleontology 17 $599-622$.

Lord, A., 1982. Metacopine Ostracoda in the Lower Jurassic. In: Banner, F.T., Lord, A.R. (Eds.), Aspect of Micropalaeontology. George Allen and Unwin, London, pp. 262-277.

Maillot, S., Mattioli, E., Guex, J., Pittet, B., 2006. The Early Toarcian anoxia, a synchronous event in the Western Tethys?. An approach by quantitative biochronology (Unitary Associations), applied on calcareous nannofossils. Palaeogeography, Palaeoclimatology, Palaeoecology 240, 562-586.

Martin, G.P.R., 1960. Mikrofauna. In: Die Zone des Dactylioceras tenuicostatum (Toarcien, Lias) in NW und SW-Deutschland. Paläontologische Zeitschrift 34 $103-149$.

Maupin, C., 1977. Données micropaléontologiques nouvelles et précisions stratigraphiques sur le Lias du Kef Ben Chikr Bou Rouhou et du Kef Toumiette Nord (Chaine Calcaire Kabyle-Nord du Constantinois, Algérie). Revue du Micropaléontologie 20, 91-99.

McElwain, J.C., Wade-Murphy, J., Hesselbo, S.P., 2005. Changes in carbon dioxide during an oceanic anoxic event linked to the intrusion into Gondwana coals. Nature 435 479-482.

Michelsen, O., 1975. Lower Jurassic biostratigraphy and ostracods of the Danish Embayment. Danmarks Geologiske Undersøgelse 104, 1-289.

Nelson, T.A., Blackwelder, P., Hood, T., McKee, B., Romer, N., Alvarez-Zarikian, C. Romer, N., Metz, S., 1994. Time-based correlation of biogenic, lithogenic and authigenic inputs in the Gulf of Mexico NECOP study area. Estuaries 17, 873-885.

Peypouquet, J.P., 1977. Les ostracodes et la connaissance des paléomilieux profonds (Thèse de doctorat d'État) Application au Cénozoique de l'Atlantique nordoriental, 552 . Universitê Bordeaux I ( $443 \mathrm{pp}$.).

Peypouquet, J.P., 1980. Les relations ostracodes-profondeur. Principes applicables pendant le Cenozoíque. Bulletin de I'Institut de Geologie du Bassin d'Aquitaine $28,13-28$.

Pietrzenuk, T., 1961. Zur Mikrofauna einiger Lias vorkommen in der Deutschen Demokratischen Republik. Freiberger Forschungshefte 113, 1-129.

Pörtner, H.O., 2010. Oxygen-and capacity-limitation of thermal tolerance: a matrix for integrating climate-related stressor effects in marine ecosystems. Journal of Experimental Biology 213, 881-893.
Riegraf, W., 1984. Neue Ostracoden-Arten aus dem Oberen Pliensbachium und Unteren Toarcium Südwestdeutschlands und Sudfrankreichs. Stuttgarter Beiträge zur Naturkunde, Serie B (Geologie und Paläontologie) 104, 1-19.

Röhl, H., Schmid-Röhl, A., Oschmann, W., Frimmel, A., Schwark, L., 2001. The Posidonian shale (Lower Toarcian) of SW-Gemany: an oxygen depleted ecosystem controlled by sea level and Palaeoclimate. Palaeogeography, Palaeoclimatology, Palaeoecology 165 , $27-52$

Rosales, L, Quesada, S., Robles, S., 2004. Paleotemperature variations of Early Jurassic seawater recorded in geochemical trends of belemnites from the Basque-Cantabrian basin, northern Spain. Palaeogeography, Palaeoclimatology, Palaeoecology 203, 253-275.

Scotese, C.R., 2001. Atlas of Earth History. Paleogeography, vol. 1. PALEOMAP Project, Arlington 1-52.

Scotese, C.R., 2003. Plate Tectonic animation, Jurassic to Quaternary. Data http://www. scotese.com (PALEOMAP website).

Struck, U., Emeis, K.-C., Voss, M., Krom, M.D., Rau, G.H., 2001. Biological productivity during sapropel S5 formation in the Eastern Mediterranean Sea: evidence from stable isotopes of nitrogen and carbon. Geochimica et Cosmochimica Acta 65, 3249-3266.

Suan, G., Pittet, B., Bour, I., Mattioli, E., Duarte, L.V., Maillot, S., 2008. Duration of the Early Toarcian carbon isotope excursion deduced from spectral analysis: consequence for its possible causes. Earth and Planetary Science Letters 267, 666-679.

Svensen, H., Planke, S., Chevallier, L., Malthe-Sørenssen, A., Corfu, F., Jamtveit, B., 2007. Hydrothermal venting of greenhouse gases triggering Early Jurassic global warming. Earth and Planetary Science Letters 256, 554-566.

Triebel, E., Bartenstein, H., 1938. Die Ostracoden des deutschen Juras. Monoceratina Arten aus dem Lias. Senckenbergiana Lethaea 20, 502-518.

Triebel, E., Klingler, W., 1959. Neue Ostracoden-Gattungen aus dem deutschen Lias. Geologie 335-372.

Van de Schootbrugge, B., McArthur, J.M., Bailey, T.R., Rosenthal, Y., Wright, J.D., Miller, K.G., 2005. Toarcian oceanic anoxic event: an assessment of global causes using belemnite $C$ isotope records. Paleoceanography 20,1-10.

Whatley, R.C., 1991. The platycopid signal: a means of detecting kenoxic events using Ostracoda. Journal of Micropalaeontology 10, 181-183.

Whatley, R.C., 1995. Ostracoda and oceanic palaeoxygen levels. Mitteilungen aus dem Hamburgischen Zoologischen Museum und Institut 92, 337-353.

Whatley, R.C., Arias, C.F., Comas Rengifo, M.J., 1994. The use of Ostracoda in detailing kenoxic events: a example from the Spanish Toarcian. Geobios 17, 733-741.

Wignall, P.B., Newton, R.J., Little, C.T.S., 2005. The timing of paleoenvironmental change and cause and effect relationships during the Early Jurassic mass extinction in Europe. American Journal of Science 305, 1014-1032.

Ziegler, P.A., 1990. Geological Atlas of Western and Central Europe 1990, 2nd ed. Shell Internationale Petroleum Maatschappij, The Hague 1-239.

Ziegler, P.A., 1992. Geological Atlas of Westem and Central Europe. Elsevier, Amsterdam $1-120$ 